\title{
Estimation of Drivers of Public Education Expenditure: Baumol's Effect Revisited
}




\title{
WP/15/178
}

\section{IMF Working Paper}

\section{Estimation of Drivers of Public Education Expenditure: Baumol's Effect Revisited}

\author{
by Manabu Nose
}

IMF Working Papers describe research in progress by the author(s) and are published to elicit comments and to encourage debate. The views expressed in IMF Working Papers are those of the author(s) and do not necessarily represent the views of the IMF, its Executive Board, or IMF management.
I $\mathrm{N}$
R N A T I O N A L
$M O N E T A R Y$
F U N D 


\title{
IMF Working Paper
}

Fiscal Affairs Department

\section{Estimation of Drivers of Public Education Expenditure: Baumol's Effect Revisited Prepared by Manabu Nose ${ }^{1}$}

\author{
Authorized for distribution by David Coady
}

July 2015

\section{IMF Working Papers describe research in progress by the author(s) and are published to elicit comments and to encourage debate. The views expressed in IMF Working Papers are those of the author(s) and do not necessarily represent the views of the IMF, its Executive Board, or IMF management.}

\begin{abstract}
This paper analyzes drivers of rising per-pupil public education spending, including Baumol's "cost disease" effect. Higher wages paid to teachers contributed significantly to the increase in per-pupil spending over the past decades. Empirical analyses using a large dataset of advanced and developing economies show that the contribution of Baumol's effect was much smaller than impled by theory. Rather, the spending inccrease reflects rising wage premiums paid for teachers in excess of market wages, especially in middleincome countries. The strong wage premium effect suggests that institutional characteristics that govern teachers' wage setting are key determinants of education expenditure.
\end{abstract}

JEL Classification Numbers: H52, I21, I25, I28

Keywords: Public education expenditure, Baumol's effect, wage premium, institutions Author's E-Mail Address: MNose@imf.org

\footnotetext{
${ }^{1}$ The author is grateful to Vitor Gaspar, Sanjeev Gupta, David Coady, Masahiro Nozaki, Baoping Shang, Benedict Clements, Julio Escolano, Lonkeng Constant, Junji Ueda, Joana Pereira, and seminar participants at the IMF's Fiscal Affairs Department for insightful comments. The views expressed herein are those of the author and should not be attributed to the IMF, its Executive Board, or its management.
} 
Abstract

I. Introduction

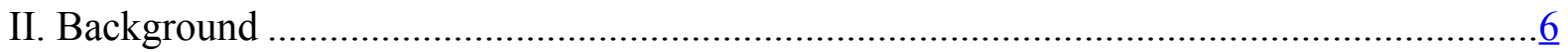

A. Decomposition of Changes in Public Education Spending …............................... $\underline{6}$

B. Decomposition of Changes in Per-Pupil Education Spending ...............................

III. A Model

IV. Data and Descriptive Analysis

A. Wage Premium in Education ................................................................ 13

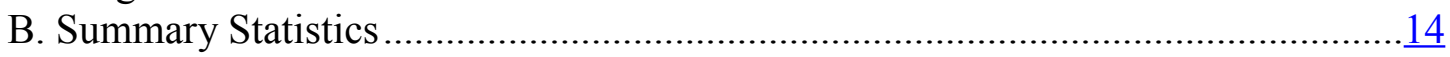

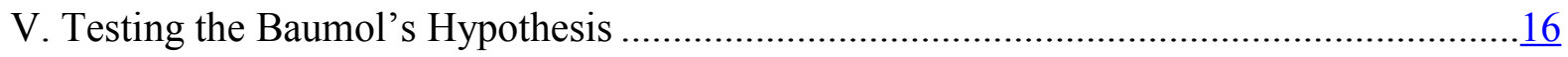

VI. Robustness Checks ...................................................................................... 18

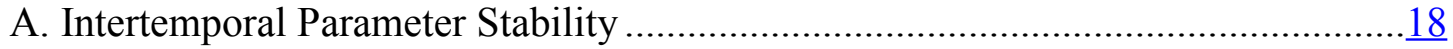

B. Asymmetry by Country Groups ................................................................. $\frac{19}{21}$

C. A Comparison between Basic and Higher Education Expenditure........................ 21

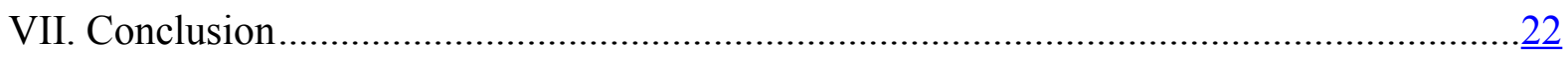

Tables

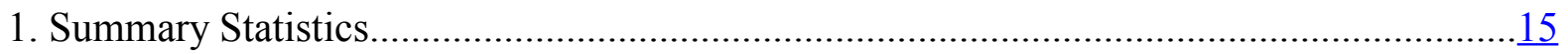

2. Estimates of First-Differenced Model …….............................................................. $\frac{17}{18}$

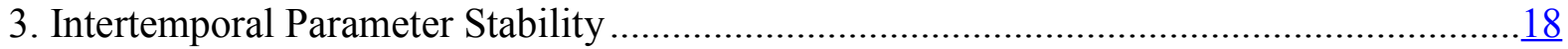

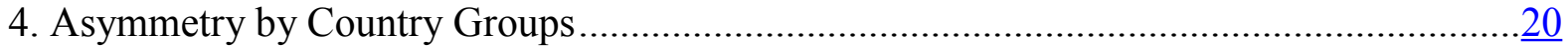

5. Asymmetry by Basic and Higher Education Spending...............................................22

Figures

1. Decomposition of Change in Education Spending, from 1997-99 to 2007-09 .................. $\underline{6}$

2. Decomposing the Change in Per-Pupil Education Spending, from 1997-99 to 2004-06..... $\underline{8}$

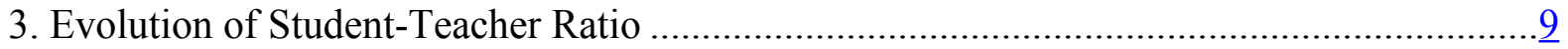

4. Testing the Common-wage Growth Assumption …..................................................12

5. The Ratio of Teachers' Salaries Relative to Manufacturing Wage .................................13

6. Evolution of the Adjusted Baumol's Variable ........................................................... 15

Appendices

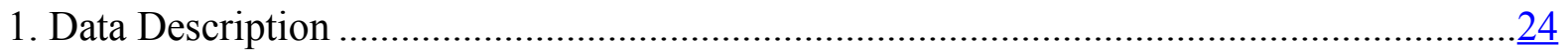

2. Panel Unit Root and Cointegration Test …............................................................

3. Wage Premium in Public Education: Case Studies in Indonesia and South Africa .............29 
Appendix Tables

1. Main Sample .$\underline{25}$

2. Panel Unit Root Test Result................................................................................ $\underline{26}$

3. Johansen Panel Cointegration Test ................................................................... $\frac{27}{28}$

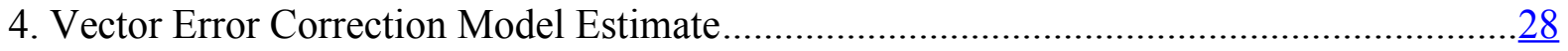

5. Wage Gap at Different Quantiles in Indonesia and South Africa.....................................

6. Decomposition Estimates in Indonesia and South Africa...............................................

Appendix Figures

1. Median Wage Gap between Public Education and Manufacturing Sector: by Level of Education Attainment .32

References $\underline{33}$ 


\section{INTRODUCTION}

Public education expenditure (PEE) constitutes a sizable part of a country's budget, and the unit cost of public education continues to rise at varying degrees around the world. At the primary and secondary school level, data from the United Nations Educational, Scientific and Cultural Organization (UNESCO) indicate that the cost has been rising persistently and, in some countries, dramatically, during the last decade. In advanced economies, the average per-pupil primary and secondary education expenditures were 18 percent and 23 percent of per capita GDP in 1995-99, which steadily rose to 20 percent and 25 percent in ten years (Wolff, Baumol, and Saini, 2014). The cost of public education has also risen in emerging and developing countries and will rise in low-income countries for the promotion of universal coverage of public education to achieve the policy target under the Millennium Development Goals (MDG).

Besides concerns about rising costs of education, growing evidence suggests that public education needs to be more efficiently delivered to promote long-term economic growth. Despite significant increases in budget allocation to education, educational performance has not improved. Some studies found critical inefficiency in public education especially in sub-Saharan African countries (Gupta and Verhoeven, 2001; Herrera and Pang, 2005; Grigoli, 2014) which suggests that public education spending could be made more cost effective.

To address these concerns, policymakers need to understand determinants of the past increase in unit cost of public education. Does the cost increase reflect demographic change or institutional factors, such as a change in education policy, wage setting, and recruitment of teachers? In public health, previous studies found that only one-fourth of the past increase in the cost of medical care can be explained by demographic factors. The rest of the cost growth (known as excess cost growth) appears to come from non-demographic factors including progress in medical technology, the Baumol's effect, and the change in health policies and institutions (IMF, 2010). ${ }^{2}$ In education, however, the factors driving higher per-pupil public education spending are still a black box.

In Baumol (1967), the service sector, such as education, is categorized as non-progressive industries that are characterized as being labor intensive in contrast to progressive (e.g., manufacturing) industries. In non-progressive industries, wage rates increase in proportion to higher wage rates in the progressive sector to retain workers despite low productivity growth (similar to the Balassa-Samuelson effect), driving up the unit cost of services in the non-progressive sector. As demand for education tends to be price inelastic, this triggers a continuous rise in public expenditure on education (the Baumol's "cost disease"

\footnotetext{
${ }^{2}$ These works include Medeiros and Schwierz (2013), Hartwig (2008), Carrion-i-Silvestre (2005), and Gerdtham and Lothgren (2000).
} 
hypothesis). ${ }^{3}$ The recent finding by Wolff, Baumol, and Saini (2014) suggests the existence of Baumol's disease in public education for Organization for Economic Cooperation and Development (OECD) countries, but the Baumol's hypothesis has not been examined in public education for emerging and developing countries.

Against this background, this paper examines driving factors of higher unit cost of public education. First, following a standard decomposition formula used in IMF (2014), it further decomposes an increase in per-pupil public education expenditure into price effect (teachers' salaries), demographic effect (teacher-pupil ratio), and other educational spending. Second, it provides a theoretical and empirical framework to identify drivers of per-pupil public expenditure including the Baumol's effect, for a sample of advanced and emerging economies much larger than that used by Wolff, Baumol, and Saini (2014). Finally, it provides sensitivity analyses to accounts for the asymmetry of these estimates by the country's income level, the quality of the public education system, and different levels of education spending (basic education vs. tertiary education).

The main results are summarized as follows. The decomposition analysis finds that the historical increase in per-pupil PEE has been driven by the growth of teachers' salaries. The regression analysis shows that Baumol's effect is much weaker than suggested by the theoretical model as well as what was found for medical care spending (see Hartwig, 2008). Instead, the rising wage premium paid to teachers in public schools (in excess of the manufacturing sector wage) contributes more significantly to the growth of per-pupil PEE. The wage premium effect on higher unit cost of public education is found to be stronger in the middle-income countries and for countries with larger classroom size. The wage premium effect drives higher cost growth in basic education, while the Baumol's effect and growth of capital education expenditure contribute more to the cost growth in tertiary education. Finally, two country case studies (in Appendix III) suggest that the rising wage premium for teachers may reflect institutional characteristics that govern teachers' wage setting.

This paper is organized as follows. Section II provides the decomposition analysis on the changes in public education spending in recent years. Section III presents the modified Baumol's model, and Section IV provides descriptive analysis on the data. Sections V and VI carry out empirical analysis. Section VII concludes.

\footnotetext{
${ }^{3}$ Nordhaus (2008) provides evidence that the Baumol's cost disease hypothesis holds in the U.S. based on the industry account data from the Bureau of Economic Analysis for the period 1948-2001. See Baumol, Ferranti, and others (2012) for the analysis on the fast-rising prices of health care and education in the United States and other advanced economies.
} 


\section{BACKGROUND}

\section{A. Decomposition of Changes in Public Education Spending}

Many countries around the world have scaled up budget allocations to education since the late-1990s. Following a standard decomposition formula as defined below, a public education spending-to-GDP ratio can be decomposed into three components: (a) school-age population (as a percent of working-age population), (b) school enrollment (also called education coverage), and (c) per-pupil spending on education (as a percent of GDP per worker).

$$
\frac{\text { Education spending }}{G D P}=\frac{\text { School }- \text { age population }}{\text { Working - age population }} \frac{\text { No. of students }}{\text { School-age population }} \frac{\frac{\text { Education spending }}{\text { No.of students }}}{\frac{\text { GDP }}{\text { Working - age population }}}
$$

While the ageing demographic trend reduces demand for public education, Figure 1 demonstrates that public education spending continued to increase owing to an increase in per-pupil education spending in many emerging countries (emerging Asia, Central Eastern Europe (CEE), and the Commonwealth of Independent State (CIS), and Latin America). In the sub-Saharan African (SSA) region, the school enrollment rate has significantly improved since the late-1990s, thereby pushing up public education spending in percent of GDP. Although the driver of public education spending (in percent of GDP) differs across regions, this figure reveals that per-pupil public education expenditure (PEE) has been the key driver of an increase in public education expenditure as similarly found by IMF (2014).

Figure 1. Decomposition of Change in Public Education Spending, from 1997-99 to 2007-09

(Percent of GDP)

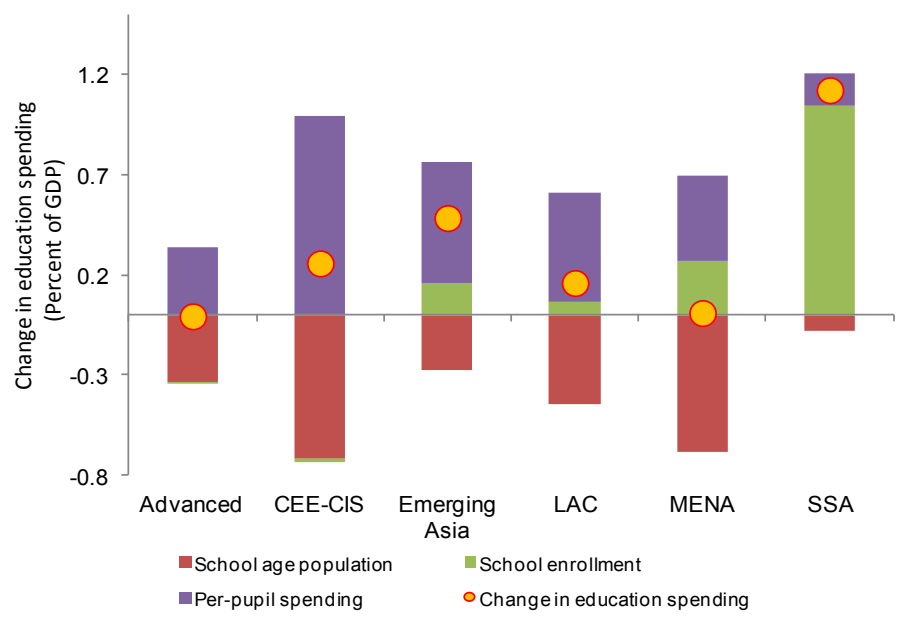

Sources: UNESCO, UN, World Development Indicators, and IMF staff calculations. Note: All ratios are median values of countries in each region. CEE-CIS $=$ Central and Eastern Europe and the Commonwealth of Independent States; LAC = Latin America and the Caribbean; MENA = Middle East and North Africa; and SSA = SubSaharan Africa. 


\section{B. Decomposition of Changes in Per-Pupil Education Spending}

To clarify the key factors driving higher per-pupil PEE, this section further decomposes per-pupil PEE (the third component of the above identity equation) into the increases in (a) teachers' salaries, (b) teacher-pupil ratios, and (c) other spending items as follows:

$$
\begin{aligned}
\frac{\text { Education spending }}{\text { No. of students }} & =\frac{\text { Wage bill }+(\text { Other current and capital education spending })}{\text { No. of students }} \\
& =\frac{\text { wage } \times \text { No. of teachers }+(\text { Other current and capital education spending })}{\text { No. of students }} \\
& =w \theta+\frac{\text { other current and capital education spending }}{\text { No. of students }}
\end{aligned}
$$

where $w$ is teachers' salaries and $\theta$ is the teacher-pupil ratio. Figure 2 shows the decomposition of the change in PEE into the change in $w, \theta$, and other spending realized between 1997-99 and 2004-06.

The figure shows that the growth of per-pupil PEE has been driven by an increase in teachers' salaries for all regions. Teachers' salaries in real terms tended to grow faster than labor productivity in advanced and non-advanced economies. In advanced economies, teachers' salaries generally grew from higher willingness to pay for public education. In developing countries, teachers had been underpaid compared with market wages, reducing teachers' motivation and driving them to opt out for other sectors (UNESCO, 2011). ${ }^{4}$ For example, in emerging European countries (such as Czech Republic, Iceland, Latvia, and Slovak Republic), teachers' salaries used to be set lower than market wages. ${ }^{5} \mathrm{~A}$ large negative wage gap also existed for teachers in public schools in Latin America (Mizala and Nopo, 2012) and sub-Saharan Africa. In recent years, however, teachers' salaries have been raised, significantly narrowing the wage gap, for example in Latin American countries (such as Nicaragua, Peru, Uruguay, and Ecuador).

For emerging economies in Asia, Middle East and North Africa (MENA) and Latin America and the Caribbean (LAC), the growth of other current and capital expenditure also contributed to higher per-pupil PEE. This could reflect the scarcity of education materials and teaching facilities in public schools as commonly observed in many developing countries.

\footnotetext{
${ }^{4}$ Advanced economies in this study comprise 27 countries: Australia, Austria, Belgium, Canada, Cyprus, Czech Republic, Denmark, Finland, France, Germany, Greece, Iceland, Ireland, Israel, Italy, Japan, South Korea, Luxembourg, Malta, New Zealand, Norway, Portugal, Spain, Sweden, Switzerland, United Kingdom, and United States.

${ }^{5}$ In several European countries (e.g., Estonia, Greece, Hungary, Ireland, and Spain), teachers' salaries were cut or frozen to deal with downturns during the 2008-09 global financial crisis.
} 
Finally, a higher teacher-pupil ratio also led to higher per-pupil PEE especially in advanced economies and the CEE-CIS regions (Figure 2). In both groups, the teacher-pupil ratio has risen with the decline in school-age population (owing to population ageing) while the number of teachers remained unchanged, leading to an overstaffed and relatively inefficient public education system. ${ }^{6}$ The contribution is smaller in developing countries where the school-age population continues to expand and the classroom tends to be oversized (more than 20 students per teacher), notably in the sub-Saharan African countries (see Figure 3).

\section{Figure 2. Decomposing the Change in Per-Pupil Education Spending, from 1997-99 to 2004-06}

(Percent of GDP per capita)

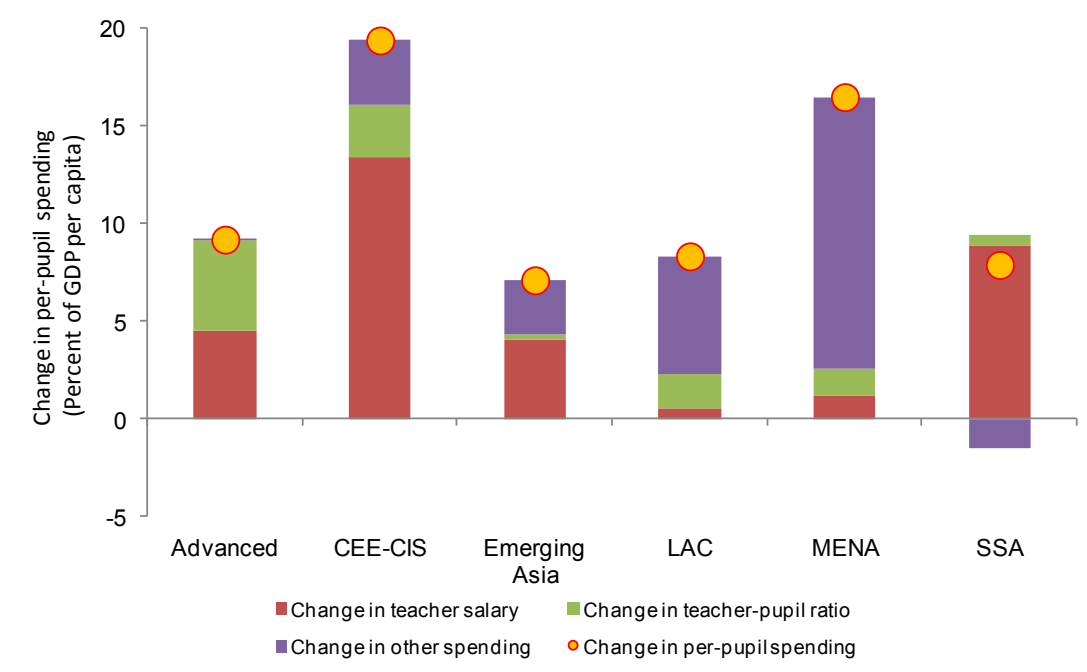

Sources: UNESCO, World Development Indicators, ILO, and IMF staff calculations.

Note: For each country, the median value of each variable during the time period (1997-99 and 2004-06) is computed. The bar chart depicts the distribution of the change in each component (median) across regions.

\footnotetext{
${ }^{6}$ For example, in Portugal, the recurrent cost of public education is large. About 95 percent is spent on compensation for teaching and non-teaching staffs (IMF, 2013).
} 
Figure 3. Evolution of Student-Teacher Ratio

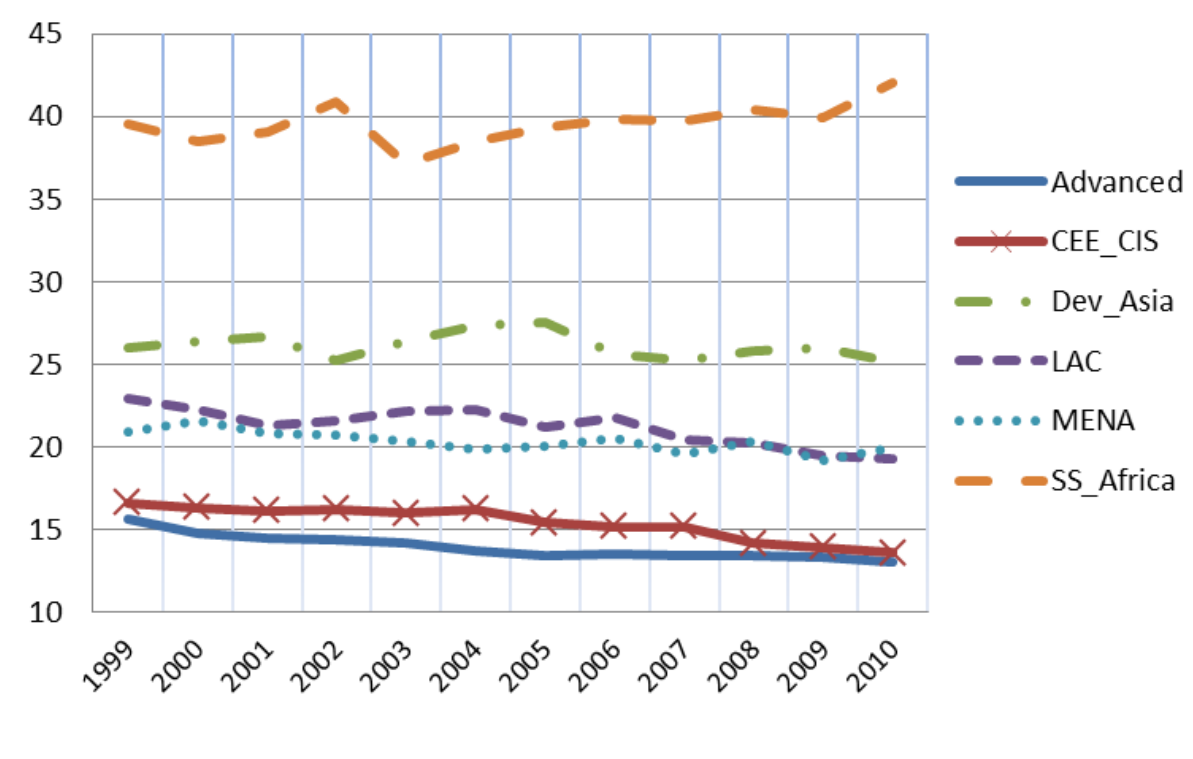

Source: World Development Indicators.

\section{A MODEL}

Based on stylized facts in Section II, this section lays out a modified Baumol's growth model (Baumol, 1967) to establish a hypothesis on the key drivers of per-pupil public education expenditure (PEE) growth.

Let us first divide the economy into two sectors: non-progressive (sector 1) and progressive (sector 2). In this paper, the non-progressive sector is the education sector. We assume that the productivity of the non-progressive sector could grow at the rate of $r_{1}$ (on account of an improvement in delivery of public education for better technology, materials, teachers, and class environment). On the other hand, the productivity in the progressive sector grows faster, at rate $r_{2}\left(r_{1}<r_{2}\right)$. For simplicity, the model assumes out capital in the production function.

$$
\begin{aligned}
& Y_{1 t}=a L_{1 t} e^{r_{1} t} \\
& Y_{2 t}=b L_{2 t} e^{r_{2} t}
\end{aligned}
$$

with $L_{1}$ and $L_{2}$ as quantities of labor employed in the non-progressive and the progressive sectors, respectively, and $a$ and $b$ as constants.

Following the classic Baumol's unbalanced growth model, nominal wages in both sectors are related in the long run and grow at labor productivity growth in the progressive sector 
(common wage growth assumption). As an extension, this paper allows some level of wage premium $\alpha_{t}$ for teachers that would differ by country and change over time. ${ }^{7}$

$$
\begin{gathered}
W_{1 t}=\left(1+\alpha_{t}\right) b e^{r_{2} t} \\
W_{2 t}=b e^{r_{2} t}
\end{gathered}
$$

The wage gap between two sectors is defined as $W_{1 t} / W_{2 t}=1+\alpha_{t}$. When $\alpha_{t}=0$, the model is same as Baumol's original model.

The Baumol's model also assumes that the output ratio of the progressive sector to the nonprogressive sector is kept constant: $\frac{Y_{2 t}}{Y_{1 t}}=\kappa$ (constant output ratio assumption). Given that this assumption holds, and total labor input of the economy at time $t$ is denoted as $L_{t}(=$ $L_{1 t}+L_{2 t}$ ), labor inputs in each sector can be expressed as follows:

$$
\begin{gathered}
L_{1 t}=\frac{L_{t}}{1+\frac{a}{b} \kappa e^{\left(r_{2}-r_{1}\right) t}} \\
L_{2 t}=\frac{\frac{a}{b} \kappa e^{\left(r_{2}-r_{1}\right) t} L_{t}}{1+\frac{a}{b} \kappa e^{\left(r_{2}-r_{1}\right) t}}
\end{gathered}
$$

Then, the unit labor cost in the non-progressive sector can be computed as: $\frac{C_{1 t}}{Y_{1 t}}=\frac{W_{1 t} L_{1 t}}{Y_{1 t}}=$ $\frac{\left(1+\alpha_{t}\right) b e^{r_{2} t}}{a e^{r_{1} t}}$. After taking the natural $\log$ of this expression and the total differentiation, the percent change in the unit labor cost of education is determined by (a) the productivity growth difference between two sectors and (b) the change in wage premium.

$$
\Delta \ln \left(\frac{C_{1 t}}{Y_{1 t}}\right)=\left(r_{2}-r_{1}\right)+\frac{\Delta \alpha_{t}}{1+\alpha_{t}}
$$

With the school-age population denoted by $N_{t}$ and following the identity equation ( $\left.\frac{C_{1 t}}{Y_{1 t}}=\frac{C_{1 t}}{N_{t}} \frac{N_{t}}{Y_{t}} \frac{Y_{t}}{Y_{1 t}}\right)$, per-pupil PEE $\left(\frac{C_{1 t}}{N_{t}}\right)$ can be decomposed into the price effect (the first two terms in Eq. 5) and the income effect.

$$
\Delta \log \left(\frac{C_{1 t}}{N_{t}}\right)=\left(r_{2}-r_{1}\right)+\frac{\Delta \alpha_{t}}{1+\alpha_{t}}+\Delta \log \left(\frac{Y_{t}}{N_{t}}\right)
$$

\footnotetext{
${ }^{7}$ The wage premium would be positive and increase over time for two reasons: (a) a higher skill premium for teachers and (b) higher rent payments, for example, because of strong collective bargaining power of labor union in the education sector and the government's intervention in the labor market via minimum wage legislation.
} 
From the constant-output ratio assumption, output share of the education sector $\left(\frac{Y_{1 t}}{Y_{t}}\right)$ is constant and will be removed from Eq. (5). This equation shows that the growth of PEE can be decomposed into three components: (a) the Baumol's effect, (b) the change in wage premium, and (c) per-pupil GDP growth.

As output is hard to measure in education, we cannot observe the productivity growth of the education sector $\left(r_{1}\right)$. Therefore, the first term in the right-hand side (RHS) of Eq. (5) needs to be replaced with the adjusted Baumol's variable. Following the method proposed by Colombier (2012) and Bates and Santerre (2013), the adjusted Baumol's variable is defined as the growth of average wage in excess of the growth of economy-wide labor productivity. The economy-wide labor productivity is expressed as $y_{t}=\frac{Y_{t}}{L_{t}}$ where total output is $Y_{t}=Y_{1 t}+Y_{2 t}=\frac{a(1+\kappa) e^{\left(r_{2}-r_{1}\right) t} L_{t}}{1+\frac{a}{b} \kappa e^{\left(r_{2}-r_{1}\right) t}}$ from Eqs. (1) and (3). Then, the economy-wide productivity growth is $\Delta \log \left(y_{t}\right)=\frac{r+\frac{a}{b} r_{1} \kappa e^{\left(r_{2}-r_{1}\right) t}}{1+\frac{a}{b} \kappa e^{\left(r_{2}-r_{1}\right) t}}$. Assuming common wage growth in two sectors, the adjusted Baumol's variable is derived as follows:

$$
\Delta \log \left(W_{t}\right)-\Delta \log \left(y_{t}\right)=\left(r_{2}-r_{1}\right) \frac{\frac{a}{b} \kappa e^{\left(r_{2}-r_{1}\right) t}}{1+\frac{a}{b} \kappa e^{\left(r_{2}-r_{1}\right) t}}=\left(r_{2}-r_{1}\right) \frac{L_{1 t}}{L_{t}}
$$

From Eqs. (5) and (6):

$$
\Delta \log \left(\frac{C_{1 t}}{N_{t}}\right)=\frac{1}{\lambda_{t}}\left[\Delta \log \left(W_{t}\right)-\Delta \log \left(y_{t}\right)\right]+\frac{\Delta \alpha_{t}}{1+\alpha_{t}}+\Delta \log \left(\frac{Y_{t}}{N_{t}}\right)
$$

where $\lambda_{t}=\frac{L_{1 t}}{L_{t}}$ (the labor share of the non-progressive sector). Finally, we account for other drivers of PEE such as capital education expenditure and other recurrent education expenditure as well as school-age population growth in Eq. (7) as defined below:

$$
\Delta \log \left(\frac{C_{1 t}}{N_{t}}\right)=\beta_{1} \frac{1}{\lambda_{t}}\left[\Delta \log \left(W_{t}\right)-\Delta \log \left(y_{t}\right)\right]+\beta_{2} \frac{\Delta \alpha_{t}}{1+\alpha_{t}}+\beta_{3} \Delta \log \left(\frac{Y_{t}}{N_{t}}\right)+\gamma \boldsymbol{Z}_{t}+u_{t}
$$

where $\boldsymbol{Z}_{\boldsymbol{i t}}$ is a matrix of regressors including the intercept for country $i$ in year $t$. The error term includes unobserved country and time effects, and a remaining idiosyncratic error component. We estimate this equation to test the following hypotheses in the empirical section. If the wage premium is constant $\left(\Delta \alpha_{t}=0\right)$, Eq. (8) is the same as Baumol's original model.

Hypotheses derived from our model are summarized as follows.

- Hypothesis 1: Baumol's effect (disease) exists if the growth of per-pupil PEE is directly proportional to the adjusted Baumol's variable, namely when $\beta_{1}=1$. 
- Hypothesis 2: To account for the wage gap between education and other sectors, price effect needs to be decomposed into the Baumol's effect and wage premium effect. If teachers are paid increasingly higher salaries compared with market wages (i.e., $\Delta \alpha_{t} \neq$ 0 , for skill difference, overcompensation, incentive payment, or other reasons), the wage premium effect will be more critical factor than the Baumol's effect.

\section{DAta AND Descriptive Analysis}

This section tests the two hypotheses in Section III using a macroeconomic panel dataset that covers 61 advanced and emerging countries from 1995 to 2009 (see Table A.1 in Appendix I for details).

First, we test two key assumptions of the Baumol's model: (a) constant output ratio and (b) common wage growth between education and manufacturing sectors. First, the constant output ratio assumption relies on the fact that public education is the luxury good (i.e., education spending is price-inelastic as hypothesized by Wagner). In Appendix II, this assumption is validated because income elasticity is close to 1 using the vector error correction model. Second, Figure 4 shows the correlation between the changes in real teachers' salaries and real manufacturing wage, which shows significant positive correlation between the two (the correlation is about 0.58 ), validating the common-wage growth assumption.

Figure 4. Testing the Common-wage Growth Assumption

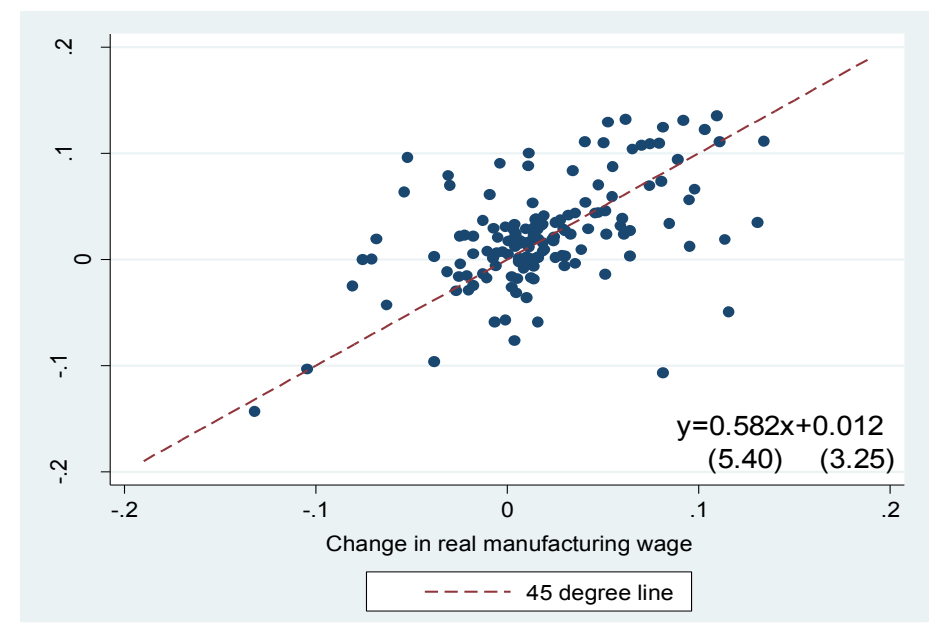

Sources: ILO and World Development Indicators.

Note: Each dot indicates the pair of average changes in real teachers' salaries and real manufacturing wage during four time periods (1999-2002, 2003-06, 2007-09, and 2010-11). The bracket in the figure shows the t-statistics of the linear regression of the change in real teachers' salaries on the change in real manufacturing wage. 


\section{A. Wage Premium in Education}

As for hypothesis 2 in the model, the wage premium tends to grow if governments offer wage adjustments or additional benefits to teachers. ${ }^{8}$ This wage-setting policy will be governed by country-specific labor market institutions, such as the wage-setting policies for public workers and the level of unionization.

Using the International Labor Organization's (ILO) wage data, Figure 5 shows the gap between teachers' salaries and market wage for countries with different initial income levels in 2000, showing a sizable wage gap between the two sectors. ${ }^{9}$ Compared with the late-1990s, the wage gap has grown in many middle-income countries as shown by the upward shift of the non-parametrical estimate of the wage premium before 2000 (dotted line) to the estimate of the wage premium after 2000 (bold line). Appendix III provides case studies for two emerging countries (Indonesia and South Africa), exploring reasons the wage premium for teachers has grown in the middle-income countries.

\section{Figure 5. The Ratio of Teachers' Salaries Relative to Manufacturing Wage}

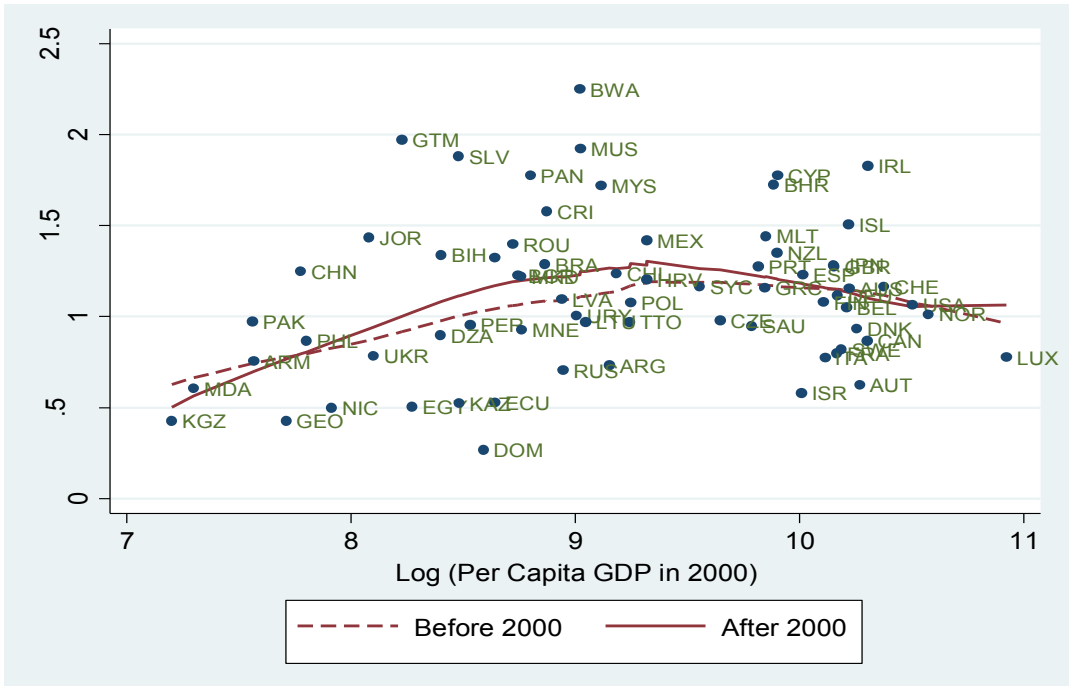

Sources: ILO, UNESCO, World Development Indicators.

Note: The bold line is the locally weighted regression estimate of the wage gap variable (computed using the median wage data after 2000) on the log of GDP per capita in purchasing power parity (PPP) US\$ in 2000. The dotted line uses the median wage gap before 2000 .

\footnotetext{
${ }^{8}$ For example, in OECD countries, governments offer wage adjustments or additional benefits on top of the base salary which tends to increase the wage bill over time. Emerging and developing countries (especially the sub-Saharan African countries) particularly face a challenge in recruiting high-quality teachers in public schools. In such countries, the government must pay a higher premium for prospective teachers compared with other occupations to retain high-skill workers in the education sector (UNESCO, 2011).

${ }^{9}$ As suggested by Clements, Gupta, and others (2010), the wage premium is measured by the gap between teacher salaries and wages of manufacturing workers in Figure 5.
} 


\section{B. Summary Statistics}

Table 1 provides summary statistics of main variables used in the empirical analysis. In the sample (see Appendix I for country list), the average public education expenditure (PEE) (in percent of GDP) is 4.4 percent, and the share of employment in public education sector is about 6 percent on average. The sample covers a wide range of countries with different levels of PEE-to-GDP ratios (from 0.9 percent at minimum to 12 percent at maximum). In 1995-2009, real per-pupil PEE increased by 3.3 percent on average. Per-pupil education spending grew faster for basic education (3.4 percent on average), while the average growth rate is negative for higher education despite a larger variance.

The adjusted Baumol's variable is computed using Eq. (6) whose mean is 3 percent. ${ }^{10}$ Figure 6 helps us understand the evolution of the Baumol's variable separately for advanced and developing economies. The Baumol's variable appears to be positive for both groups (particularly large for developing countries but with larger variance) except during the post-global financial crisis period in 2010-11 owing to the rebound of GDP growth. This suggests that the Baumol's effect could be one of the determinants of higher per-pupil PEE.

In Section V, two wage premium measures will be used as suggested by Clements, Gupta, and others (2010). The first variable ( $\Delta$ wage premium 1 ; measured as the ratio of teachers' salaries relative to GDP per capita) is zero on average, but ranges from -25 percent at minimum to 39 percent at maximum. Another variable ( $\Delta$ wage premium 2 ; measured as the ratio of teachers' salaries relative to manufacturing wage) has larger variance with smaller sample size because of missing data for the manufacturing wage.

Finally, capital education expenditure growth was high at 4 percent at median. The teacherpupil ratio increased in advanced economies, reflecting a decline in school-age population due to population ageing.

\footnotetext{
${ }^{10}$ Outliers are trimmed out at the top and bottom 5 percent to minimize the measurement error of the Baumol's variable.
} 
Table 1. Summary Statistics

\begin{tabular}{|c|c|c|c|c|c|c|}
\hline & $\mathrm{N}$ & Mean & Median & Std Dev. & Min & Max \\
\hline \multicolumn{7}{|l|}{ Public education expenditure variables } \\
\hline Public education expenditure/GDP & 1507 & 4.419 & 4.325 & 1.714 & 0.009 & 11.988 \\
\hline$\Delta \ln ($ per-pupil education expenditure) & 1126 & 0.033 & 0.029 & 0.167 & -0.738 & 1.099 \\
\hline$\Delta \ln ($ per-pupil basic education expenditure) & 1023 & 0.034 & 0.027 & 0.249 & -1.657 & 2.076 \\
\hline$\Delta \ln ($ per-pupil higher education expenditure) & 969 & -0.022 & -0.007 & 0.507 & -2.554 & 2.792 \\
\hline$\Delta \ln ($ per-pupil wage bill in public education) & 851 & 0.039 & 0.036 & 0.135 & -0.614 & 0.964 \\
\hline \multicolumn{7}{|l|}{$\underline{\text { Other variables }}$} \\
\hline Share of labor in public education sector & 1560 & 0.059 & 0.059 & 0.025 & 0.055 & 0.128 \\
\hline$\Delta \ln ($ per capita GDP in PPP\$) & 417 & 0.046 & 0.048 & 0.042 & -0.148 & 0.159 \\
\hline Adj. Baumol's variable & 417 & 0.031 & 0.020 & 0.705 & -1.887 & 1.956 \\
\hline$\Delta$ wage premium 1 & 417 & 0.001 & 0.000 & 0.059 & -0.254 & 0.387 \\
\hline$\Delta$ wage premium 2 & 302 & 0.000 & 0.002 & 0.097 & -0.723 & 0.771 \\
\hline$\Delta \ln ($ capital expenditure in education) & 417 & 0.028 & 0.039 & 0.343 & -3.491 & 1.853 \\
\hline$\Delta \ln ($ teacher-pupil ratio) & 417 & 0.237 & 0.178 & 0.589 & -2.699 & 6.024 \\
\hline
\end{tabular}

Sources: UNESCO Institute for Statistics, ILO, OECD, and World Development Indicators.

Note: Public education expenditure variables and the labor share in public education sector cover all observations available in the data during the sampling period (1995-2009). For others, the summary statistics cover observations for non-missing observations used in the regression in Table 2.

Variable definition: $\Delta$ wage premium 1: the growth of teachers' salaries relative to GDP per capita; $\Delta$ wage premium 2: the growth of teachers' salaries relative to manufacturing wage.

Figure 6. Evolution of the Adjusted Baumol's Variable

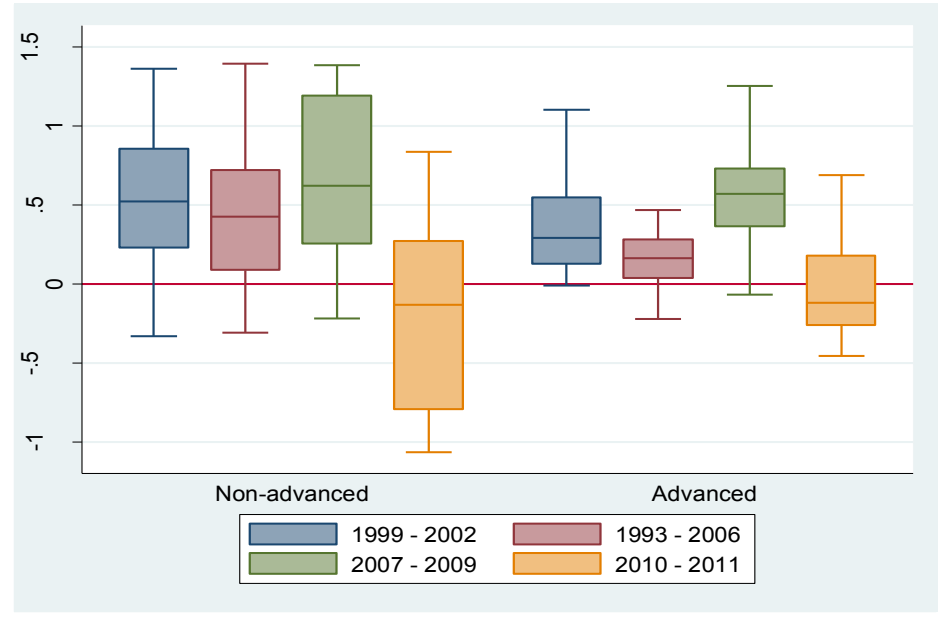

Sources: ILO, World Development Indicators, and IMF staff calculations.

Note: For each country group and time period, the box plot depicts the distribution of the adjusted Baumol's variable (maximum of each time period), with the middle line indicating median, the lower and upper boundaries of the box $25^{\text {th }}$ and $75^{\text {th }}$ percentiles, respectively, and the lower and upper lines $10^{\text {th }}$ and $90^{\text {th }}$ percentiles, respectively. 


\section{Testing The Baumol's Hypothesis}

This section estimates the first-differenced model as defined in Eqs. (7)-(8). Although main variables used in the estimation are non-stationary, the first-differenced series rejects the null hypothesis of the unit root (see the unit root test in Appendix II).

As predicated by theoretical hypothesis 1 , the coefficient of $\beta_{1}$ should be 1 to strongly support the Baumol's (cost disease) hypothesis in public education. The wage premium variable is added to estimate the contribution of teachers' wage policy to higher per-pupil public education expenditure (PEE) separately from the Baumol's effect.

We start the analysis by estimating the determinants of an increase in unit labor cost (i.e., wage bill) in education. To estimate other cost factors of education, we consider how much the demographic factor (the change in school-age population) and the change in capital expenditure in education (e.g., school construction, new technology) contributed to higher per-pupil PEE. The regression also controls for a dummy of high level of private education spending (which is one for countries whose private education expenditure-to-GDP ratio is larger than the sample average) as private education could substitute for public education. Country and year fixed effects are included to remove bias owing to country- and yearspecific time-invariant unobservable cost factors. ${ }^{11}$

\section{Result}

Columns 1-4 of Table 2 estimate the growth of per-pupil wage cost for public education (with regional fixed effects in columns 1-2 and with country fixed effects in columns 3-4), while columns 5-8 estimate the growth of per-pupil PEE. As indicated above, two wage premium variables are used: (i) the change in wage premium for teachers' salaries compared with GDP per capita ( $\Delta$ wage premium 1$)$ and (ii) the change in wage premium for teachers' salaries compared with manufacturing wage ( $\Delta$ wage premium 2 ).

The result in columns 1-4 only weakly supports the Baumol's hypothesis while it shows a stronger wage premium effect. The adjusted Baumol's variable is positive and significant after controlling for country fixed effects, but the coefficient is much smaller than 1 . The weaker than expected Baumol's effect suggests that policy factors governing the wagesetting policy in public education might be more critical in increasing the unit labor cost. To explore this channel, columns 2-4 add the wage premium variables. For both wage premium measures, the wage premium effect is significant and has a larger effect on the growth of unit labor cost.

\footnotetext{
${ }^{11}$ The Hausman test rejects the null hypothesis that the random effect estimator is consistent, which supports the adoption of the fixed effects model.
} 
For other variables, the change in real GDP per capita and teacher-pupil ratio also significantly contribute to a higher unit cost of education. ${ }^{12}$

When an outcome variable is replaced with the change in per-pupil PEE in columns 5-8, both the Baumol's effect and the wage premium effect remain significant. The point estimate of the wage premium variable gets smaller than the estimates in column $1-4$, but it still has a large effect on the per-pupil PEE growth. In this specification, the change in capital education expenditure is proven to contribute to higher per-pupil PEE as expected, but with smaller magnitude compared with the wage premium effect.

This result demonstrates that strong wage effect on the change in per-pupil PEE, as found in Figure 2, is largely driven by the change in the wage premium while the Baumol's effect is much weaker in the context of public education compared to medical care spending.

Table 2. Estimates of First-Differenced Model

\begin{tabular}{|c|c|c|c|c|c|c|c|c|}
\hline \multirow{3}{*}{$\begin{array}{l}\text { VARIABLES } \\
\text { Adj. Baumol's variable }\end{array}$} & (1) & $(2)$ & $(3)$ & (4) & (5) & (6) & (7) & (8) \\
\hline & \multicolumn{4}{|c|}{$\Delta \ln ($ real per pupil wage bill) } & \multicolumn{4}{|c|}{$\Delta \ln ($ real per pupil education expenditure) } \\
\hline & $\begin{array}{c}0.052^{* \star *} \\
(0.010)\end{array}$ & $\begin{array}{c}0.032^{\star \star \star} \\
(0.009)\end{array}$ & $\begin{array}{c}0.038^{\star \star *} \\
(0.009)\end{array}$ & $\begin{array}{c}0.058^{\star \star \star} \\
(0.010)\end{array}$ & $\begin{array}{l}0.043^{* \star *} \\
(0.009)\end{array}$ & $\begin{array}{c}0.034^{\star \star *} \\
(0.008)\end{array}$ & $\begin{array}{c}0.035^{\star \star \star} \\
(0.011)\end{array}$ & $\begin{array}{c}0.044^{* * *} \\
(0.013)\end{array}$ \\
\hline$\Delta \mathrm{w}$ age premium 1 & & $\begin{array}{c}0.649^{\star \star \star} \\
(0.114)\end{array}$ & $\begin{array}{l}0.555^{\star \star \star} \\
(0.146)\end{array}$ & & & $\begin{array}{l}0.329^{\star \star *} \\
(0.082)\end{array}$ & $\begin{array}{c}0.303^{* * *} \\
(0.085)\end{array}$ & \\
\hline$\Delta \mathrm{w}$ age premium 2 & & & & $\begin{array}{c}0.470^{\star \star *} \\
(0.112)\end{array}$ & & & & $\begin{array}{l}0.250^{\star *} \\
(0.094)\end{array}$ \\
\hline$\Delta \ln ($ GDP per capita in PPP\$) & $\begin{array}{l}1.175^{\star \star *} \\
(0.213)\end{array}$ & $\begin{array}{l}1.204^{* * *} \\
(0.187)\end{array}$ & $\begin{array}{c}0.743^{\star \star *} \\
(0.155)\end{array}$ & $\begin{array}{c}0.845^{\star \star \star} \\
(0.254)\end{array}$ & $\begin{array}{c}0.964^{* * *} \\
(0.177)\end{array}$ & $\begin{array}{c}0.988^{* * *} \\
(0.169)\end{array}$ & $\begin{array}{c}0.565^{\star * *} \\
(0.139)\end{array}$ & $\begin{array}{l}0.352 \\
(0.234)\end{array}$ \\
\hline$\Delta \ln ($ real capital expenditure in education) & & & & & $\begin{array}{c}0.076^{\star \star \star} \\
(0.021)\end{array}$ & $\begin{array}{c}0.072^{\star \star \star} \\
(0.022)\end{array}$ & $\begin{array}{c}0.072^{\star \star \star} \\
(0.015)\end{array}$ & $\begin{array}{c}0.092^{\star \star \star} \\
(0.024)\end{array}$ \\
\hline$\Delta \ln$ (teacher-pupil ratio) & $\begin{array}{c}0.014^{*} \\
(0.007)\end{array}$ & $\begin{array}{c}0.019^{\star \star \star} \\
(0.007)\end{array}$ & $\begin{array}{l}0.015^{\star \star} \\
(0.007)\end{array}$ & $\begin{array}{c}0.012^{*} \\
(0.007)\end{array}$ & $\begin{array}{l}0.001 \\
(0.005)\end{array}$ & $\begin{array}{l}0.004 \\
(0.005)\end{array}$ & $\begin{array}{l}0.004 \\
(0.007)\end{array}$ & $\begin{array}{l}0.002 \\
(0.007)\end{array}$ \\
\hline High level of private education & $\begin{array}{l}0.018 \\
(0.011)\end{array}$ & $\begin{array}{l}0.014 \\
(0.010)\end{array}$ & & & $\begin{array}{l}0.014 \\
(0.009)\end{array}$ & $\begin{array}{l}0.013 \\
(0.009)\end{array}$ & & \\
\hline Constant & $\begin{array}{l}-0.082 \\
(0.053)\end{array}$ & $\begin{array}{l}-0.083^{*} \\
(0.049)\end{array}$ & $\begin{array}{c}0.011 \\
(0.008)\end{array}$ & $\begin{array}{c}0.001 \\
(0.015)\end{array}$ & $\begin{array}{c}-0.080^{\star *} \\
(0.041)\end{array}$ & $\begin{array}{l}-0.077^{*} \\
(0.040)\end{array}$ & $\begin{array}{c}0.011 \\
(0.007)\end{array}$ & $\begin{array}{c}0.018 \\
(0.014)\end{array}$ \\
\hline Observations & 401 & 401 & 401 & 284 & 417 & 417 & 417 & 295 \\
\hline Number of countries & 53 & 53 & 53 & 43 & 55 & 55 & 55 & 45 \\
\hline Region and year FEs & $\mathrm{Y}$ & $\mathrm{Y}$ & & & $\mathrm{Y}$ & $\mathrm{Y}$ & & \\
\hline Country and year FEs & & & $\mathrm{Y}$ & $\mathrm{Y}$ & & & $\mathrm{Y}$ & $\mathrm{Y}$ \\
\hline R-squared & 0.300 & 0.412 & 0.495 & 0.496 & 0.301 & 0.331 & 0.445 & 0.493 \\
\hline
\end{tabular}

${ }^{* * *} p<0.01,{ }^{* *} p<0.05,{ }^{*} p<0.1$; robust standard errors are in parentheses. Outliers of the Baumol's variable are trimmed out at the top and bottom 5 percentile.

Variable definition: $\Delta$ wage premium 1: the growth of teachers' salaries relative to GDP per capita; $\Delta$ wage premium 2 : the growth of teachers' salaries relative to manufacturing wage

\footnotetext{
${ }^{12}$ The estimates remain robust when per capita GDP growth and the change in teacher-pupil ratio are replaced with per-pupil GDP growth and the change in school-age population.
} 


\section{Robustness CHECKS}

\section{A. Intertemporal Parameter Stability}

This subsection performs a robustness check on the stability of parameters in Table 2 by splitting the estimation period of the past 10 years into subperiods, namely 1999-2006 (before the 2007-08 global financial crisis) and 2007-09 (during the crisis). Many countries faced tighter budget constraints during the crisis and implemented large expenditure-based fiscal adjustments. In many countries, the government needed to cut the wage bill by reducing public employment (including teachers and doctors in public institutions) and teachers' salaries. Therefore, we should expect weaker wage premium effect in the post-crisis period.

Table 3 estimates the determinants of the change in the real per-pupil wage bill and real per-pupil public education expenditure (PEE) for the pre-crisis and during-crisis period separately. The coefficients of the adjusted Baumol's variable remain much smaller than unity, and the wage premium remains significantly large (slightly larger than the one for the whole sample in Table 2) during the pre-crisis period.

\section{Table 3. Intertemporal Parameter Stability}

\begin{tabular}{|c|c|c|c|c|}
\hline \multirow[b]{2}{*}{ VARIABLES } & $\begin{array}{c}(1) \\
\Delta \ln (\text { real per }\end{array}$ & $\begin{array}{c}\text { (2) } \\
\text { pil w age bill) }\end{array}$ & \multicolumn{2}{|c|}{$\begin{array}{c}\Delta \ln (\text { real per pupil education } \\
\text { expenditure })\end{array}$} \\
\hline & $1999-2006$ & $2007-2009$ & $1999-2006$ & $2007-2009$ \\
\hline Adj. Baumol's variable & $\begin{array}{l}0.047^{\star * *} \\
(0.011)\end{array}$ & $\begin{array}{l}0.006 \\
(0.016)\end{array}$ & $\begin{array}{c}0.043^{\star * *} \\
(0.014)\end{array}$ & $\begin{array}{l}0.025 \\
(0.020)\end{array}$ \\
\hline$\Delta \mathrm{w}$ age premium 1 & $\begin{array}{c}0.556^{\star * *} \\
(0.194)\end{array}$ & $\begin{array}{l}0.652^{* *} \\
(0.252)\end{array}$ & $\begin{array}{l}0.471^{* * *} \\
(0.105)\end{array}$ & $\begin{array}{l}0.045 \\
(0.143)\end{array}$ \\
\hline$\Delta \ln ($ GDP per capita in PPP\$) & $\begin{array}{l}0.983^{\star *} \\
(0.398)\end{array}$ & $\begin{array}{l}0.291 \\
(0.181)\end{array}$ & $\begin{array}{c}0.798^{* * *} \\
(0.277)\end{array}$ & $\begin{array}{l}0.368^{* *} \\
(0.170)\end{array}$ \\
\hline$\Delta \ln ($ real capital expenditure in education) & & & $\begin{array}{c}0.104^{* * *} \\
(0.021)\end{array}$ & $\begin{array}{l}0.025 \\
(0.017)\end{array}$ \\
\hline$\Delta \ln$ (teacher-pupil ratio) & $\begin{array}{l}0.012 \\
(0.008)\end{array}$ & $\begin{array}{l}0.007 \\
(0.012)\end{array}$ & $\begin{array}{c}0.007 \\
(0.007)\end{array}$ & $\begin{array}{c}-0.012 \\
(0.014)\end{array}$ \\
\hline Constant & $\begin{array}{c}0.000 \\
(0.022)\end{array}$ & $\begin{array}{l}0.035^{* * *} \\
(0.008)\end{array}$ & $\begin{array}{l}-0.007 \\
(0.015)\end{array}$ & $\begin{array}{l}0.036^{* * *} \\
(0.008)\end{array}$ \\
\hline Observations & 259 & 116 & 270 & 121 \\
\hline Number of countries & 48 & 45 & 50 & 47 \\
\hline Country and year FEs & Y & $\mathrm{Y}$ & $\mathrm{Y}$ & $\mathrm{Y}$ \\
\hline R-squared & 0.546 & 0.591 & 0.516 & 0.656 \\
\hline
\end{tabular}

${ }^{* * *} p<0.01,{ }^{* *} p<0.05,{ }^{*} p<0.1$; robust standard errors are in parenthesis. Outliers of the Baumol's variable are trimmed out at the top and bottom 5 percent.

Variable definition: $\Delta$ wage premium 1: the growth of teachers' salaries relative to GDP per capita. 


\section{B. Asymmetry by Country Groups}

This subsection deals with heterogeneity in the main results by the type of country. For example, IMF (2014) discusses the heterogeneity of the Baumol's effect in general government expenditure between advanced and emerging countries, claiming that price effect dominates in advanced economies while an increase in volume of goods and services drives higher general government expenditure in emerging economies. Similar heterogeneity might also exist in public education expenditure.

As predicted by hypotheses 2 and 3 in Section III, the middle- to low-income countries would face stronger demand for public education for a variety of reasons. In general, they need to spend more on public education as private education is underdeveloped. Aside from the Baumol's disease, the scarcity in both physical and human capital (e.g., unavailability of schools, the shortage of trained teachers) requires governments to increase public education spending to achieve the universal coverage of public education. ${ }^{13}$ The scale-up of PEE would be more effective in improving efficiency in countries where the economic and social returns of education are higher, which is typically the case in developing countries. ${ }^{14}$

To test the asymmetry across country groups, Eq. (8) is estimated with interaction terms of the adjusted Baumol's variable and the wage premium variable with (a) an advanced economy dummy, (b) dummies that indicate high-income countries (HICs) or middleincome countries (MICs), and (c) a dummy for countries with small classroom size (less than 16 students per teacher). ${ }^{15}$

\section{Result}

In Table 4, the estimates in columns 1, 3, 5, 7 are for the whole sample and columns 2, 4, 6, 8 are for observations only before the global financial crisis. In columns 1 and 2, compared with the estimates in Tables 2 and 3, both the Baumol's effect and the wage premium effect appear to be significantly stronger for developing economies than advanced economies.

\footnotetext{
${ }^{13}$ Glewwe and Kremer (2006) points out that there is scarcity of trained teachers at the primary level especially in sub-Saharan Africa and South Asia, where the student-teacher ratio is quite high compared with other regions (see Figure 3). In Africa, UNESCO (2011) reports that African countries need to increase the number of teachers by 1 million by 2015 to provide primary education services with sufficient quality.

${ }^{14}$ Psacharopoulos and Patrinos (2004) presents the latest estimates of the return to investment in education covering 98 countries, which shows (a) falling returns to education as the economy develops and (b) increasing private returns to higher education. The returns are shown to be the highest for low-income and middle-income countries, especially in the Latin America and the sub-Saharan African regions.

${ }^{15}$ As shown in Appendix Table A.1, the sample does not cover most of the low-income countries because of the unavailability of wage data. Given that incentive effect would be more critical in LICs, the sample selection is likely to attenuate the Baumol's effect and the wage premium effect for low-income countries, and therefore the estimates in Table 4 would only represent the lower-bound of the true effect.
} 
Columns 3-6 examine the asymmetry of the wage effect by countries' income group, which shows weaker Baumol's effect in HICs and stronger Baumol's effect and wage premium effect for MICs. This is consistent with an increase in the wage premium for MICs as found in Figure 5 and the larger contribution of an increase in teachers' salaries to per-pupil PEE growth as shown in Figure 2.

A stronger wage premium effect for MICs would be governed by their institutional and policy environment. As discussed above, it is likely to reflect the government's policy to raise teachers' compensation for building incentives to attract qualified and motivated teachers.

Finally, in columns 7 and 8, the wage premium effect appears to be significantly positive only for countries with large classroom size which may reflect needs for the authorities in developing countries to recruit more qualified teachers by paying higher salary. ${ }^{16}$

\section{Table 4. Asymmetry by Country Groups}

\begin{tabular}{|c|c|c|c|c|c|c|c|c|}
\hline \multirow[b]{2}{*}{ VARIABLES } & (1) & (2) & (3) & (4) & (5) & (6) & (7) & (8) \\
\hline & \multicolumn{8}{|c|}{$\Delta \ln ($ real per pupil education expenditure) } \\
\hline Adj. Baumol's variable $=x$ & $\begin{array}{l}0.049^{* * *} \\
(0.014)\end{array}$ & $\begin{array}{c}0.055^{\star * *} \\
(0.017)\end{array}$ & $\begin{array}{l}0.049^{* * *} \\
(0.014)\end{array}$ & $\begin{array}{c}0.055^{\star * *} \\
(0.018)\end{array}$ & $\begin{array}{c}0.015 \\
(0.010)\end{array}$ & $\begin{array}{l}0.016 \\
(0.015)\end{array}$ & $\begin{array}{c}0.021 \\
(0.016)\end{array}$ & $\begin{array}{c}0.022 \\
(0.019)\end{array}$ \\
\hline$\Delta \mathrm{w}$ age premium $1=\mathrm{y}$ & $\begin{array}{l}0.338^{\star * *} \\
(0.102)\end{array}$ & $\begin{array}{l}0.618^{\star * *} \\
(0.165)\end{array}$ & $\begin{array}{l}0.302^{* * *} \\
(0.100)\end{array}$ & $\begin{array}{l}0.595^{\star * *} \\
(0.174)\end{array}$ & $\begin{array}{l}0.298^{\star \star} \\
(0.130)\end{array}$ & $\begin{array}{l}0.231^{*} \\
(0.123)\end{array}$ & $\begin{array}{l}0.533^{\star * *} \\
(0.150)\end{array}$ & $\begin{array}{l}0.541^{* * *} \\
(0.185)\end{array}$ \\
\hline$x$ *Advanced & $\begin{array}{c}-0.043^{* * *} \\
(0.015)\end{array}$ & $\begin{array}{l}-0.043^{* *} \\
(0.020)\end{array}$ & & & & & & \\
\hline$y *$ Advanced & $\begin{array}{l}-0.181 \\
(0.136)\end{array}$ & $\begin{array}{c}-0.561^{* * *} \\
(0.197)\end{array}$ & & & & & & \\
\hline$x * \mathrm{HIC}$ & & & $\begin{array}{c}-0.041^{* \star *} \\
(0.015)\end{array}$ & $\begin{array}{l}-0.038^{*} \\
(0.022)\end{array}$ & & & & \\
\hline$y *{ }^{*} \mathrm{HC}$ & & & $\begin{array}{c}0.017 \\
(0.161)\end{array}$ & $\begin{array}{l}(0.358) \\
(0.216)\end{array}$ & & & & \\
\hline $\mathrm{x}$ * MIC & & & & & $\begin{array}{c}0.033^{*} \\
(0.017)\end{array}$ & $\begin{array}{c}0.039^{*} \\
(0.022)\end{array}$ & & \\
\hline$y$ * MIC & & & & & $\begin{array}{l}0.005 \\
(0.163)\end{array}$ & $\begin{array}{l}0.367^{*} \\
(0.217)\end{array}$ & & \\
\hline$x$ * Small class size & & & & & & & $\begin{array}{l}0.022 \\
(0.021)\end{array}$ & $\begin{array}{c}0.031 \\
(0.024)\end{array}$ \\
\hline$y *$ Small class size & & & & & & & $\begin{array}{l}-0.360^{*} \\
(0.186)\end{array}$ & $\begin{array}{c}-0.119 \\
(0.268)\end{array}$ \\
\hline Observations & 417 & 270 & 417 & 270 & 417 & 270 & 417 & 270 \\
\hline Number of countries & 55 & 50 & 55 & 50 & 55 & 50 & 55 & 50 \\
\hline Sample & All & Pre-crisis & All & Pre-crisis & All & Pre-crisis & All & Pre-crisis \\
\hline Country and year FEs & $\mathrm{Y}$ & $\mathrm{Y}$ & $\mathrm{Y}$ & $\mathrm{Y}$ & $\mathrm{Y}$ & $\mathrm{Y}$ & $\mathrm{Y}$ & Y \\
\hline R-squared & 0.468 & 0.544 & 0.463 & 0.533 & 0.459 & 0.533 & 0.452 & 0.523 \\
\hline
\end{tabular}

${ }^{* * *} p<0.01,{ }^{* *} p<0.05,{ }^{*} p<0.1$; robust standard errors in parentheses. Outliers of the Baumol's variable are trimmed out at the top and bottom 5 percent. Country-year observations are categorized into small classroom size when pupil-teacher ratio is less than 16 . The regression also controls for the growth of real GDP per capita, the growth of real capital expenditure, the change in teacher-pupil ratio, and the level effect of small class size dummy.

Variable definition: $\Delta$ wage premium 1: the growth or teachers' salaries relative to GDP per capita.

\footnotetext{
${ }^{16}$ This does not mean that smaller size of classroom is always better for improving student performance. See Mishel and Rothstein (2002) for this line of research.
} 


\section{A Comparison between Basic and Higher Education Expenditure}

Finally, the same model is estimated for basic (primary and secondary) and higher (tertiary) education expenditure separately. Because tertiary education has a distinct nature from basic education, the driver of unit cost growth should differ between the two types of education. In terms of budget, basic education expenditure makes up about 70-75 percent of total public education expenditure, leaving only a small portion to tertiary education. As shown in Table 1, the average growth rate of per-pupil tertiary education expenditure is negative which differs substantially across countries. Tertiary education involves spending for research and development $(\mathrm{R} \& \mathrm{D})$ and information technology, while recurrent spending is the major spending component for basic education. While basic education is compulsory with its curriculum determined by the government, higher education is optional; and private schools could play a greater role in offering a variety of programs as substitutes for public universities.

In Table 5, the dependent variable is replaced with the change in real basic education expenditure (column 1) and the change in real higher education expenditure (column 2). Besides ordinary least squares (OLS) regressions, we also show the estimate of median regressions to account for a large variance associated with the change in higher education expenditure.

Results in Table 5 show that the estimates for basic education are similar to results in Table 2 for total per-pupil PEE. The median regression estimate shows stronger wage premium effect for basic education spending which suggests that per-pupil basic education spending is more affected by the change in the government's wage-setting policy. The median regression also reveals that the Baumol's effect contributes more in magnitude to higher education expenditure (although the coefficient is still smaller than 1), suggesting that teachers' salaries in tertiary education tend to be adjusted more on par with market wages. Finally, the change in real capital expenditure in education makes a larger contribution to an increase in the unit cost growth of higher education, which reflects that larger capital spending in information technology and advanced laboratory facilities drive the growth in higher education expenditure. 
Table 5. Asymmetry by Basic and Higher Education Spending

\begin{tabular}{|c|c|c|c|c|}
\hline \multirow[b]{2}{*}{ VARIABLES } & \multicolumn{2}{|c|}{$\begin{array}{c}(1) \\
\Delta \ln (\text { real per pupil basic } \\
\text { education spending) }\end{array}$} & \multicolumn{2}{|c|}{$\begin{array}{c}(2) \\
\Delta \ln (\text { real per pupil higher } \\
\text { education spending) }\end{array}$} \\
\hline & Mean & Median & Mean & Median \\
\hline Adj. Baumol's variable & $\begin{array}{l}0.049^{\star *} \\
(0.019)\end{array}$ & $\begin{array}{l}0.032^{*} \\
(0.019)\end{array}$ & $\begin{array}{l}0.070^{\star *} \\
(0.028)\end{array}$ & $\begin{array}{l}0.063^{\star \star} \\
(0.030)\end{array}$ \\
\hline$\Delta \mathrm{w}$ age premium 1 & $\begin{array}{c}0.274^{*} \\
(0.147)\end{array}$ & $\begin{array}{l}0.451^{*} \\
(0.265)\end{array}$ & $\begin{array}{l}0.190 \\
(0.239)\end{array}$ & $\begin{array}{l}0.245 \\
(0.290)\end{array}$ \\
\hline$\Delta \ln ($ GDP per capita in PPP\$) & $\begin{array}{c}0.834^{*} \\
(0.417)\end{array}$ & $\begin{array}{l}0.525 \\
(0.367)\end{array}$ & $\begin{array}{l}0.753^{\star *} \\
(0.341)\end{array}$ & $\begin{array}{l}0.786 \\
(0.852)\end{array}$ \\
\hline$\Delta \ln ($ real capital expenditure in education) & $\begin{array}{l}0.097^{\star * *} \\
(0.021)\end{array}$ & $\begin{array}{l}0.093^{* \star *} \\
(0.034)\end{array}$ & $\begin{array}{l}0.112^{\star \star \star} \\
(0.031)\end{array}$ & $\begin{array}{l}0.130^{\star \star} \\
(0.059)\end{array}$ \\
\hline Constant & $\begin{array}{l}(0.019) \\
(0.027)\end{array}$ & $\begin{array}{l}0.034 \\
(0.030)\end{array}$ & $\begin{array}{l}(0.033) \\
(0.020)\end{array}$ & $\begin{array}{l}(0.019) \\
(0.070)\end{array}$ \\
\hline Observations & 267 & 267 & 254 & 254 \\
\hline Number of countries & 50 & 50 & 49 & 49 \\
\hline Sample & Pre-crisis & Pre-crisis & Pre-crisis & Pre-crisis \\
\hline Country and year FEs & $\mathrm{Y}$ & $\mathrm{Y}$ & $\mathrm{Y}$ & Y \\
\hline R-squared & 0.397 & 0.279 & 0.278 & 0.193 \\
\hline
\end{tabular}

${ }^{* * *} p<0.01,{ }^{* *} p<0.05,{ }^{*} p<0.1$; Robust standard errors in parentheses. Outliers of the Baumol's variable are trimmed out at the top and bottom 5 percent. To minimize measure errors, outliers of real basic and higher education spending growth (top and bottom 3 percent) are also trimmed out. The regression also controls for the change in school-age population in basic education (for column 1) and higher education (in column 2).

Variable definition: $\Delta$ wage premium 1: the growth of teachers' salaries relative to GDP per capita.

\section{CONCLUSION}

This paper examined the determinants of a steady increase in public education expenditure (PEE) by analyzing the drivers of a rapid increase in per-pupil PEE, a residual component that has been less studied in the literature. Baumol's model of "unbalanced growth" is revisited and the Baumol's (cost disease) hypothesis is formally tested in the context of public education using a new macroeconomic panel dataset covering advanced and emerging economies.

This paper addressed two issues. First, the decomposition analysis highlights that the persistent rise in per-pupil PEE has been largely driven by the change in teachers' salaries. Next, the modified Baumol's model is used to identify whether the Baumol's effect has driven this wage growth and explains the per-pupil PEE growth, or policy factors (called wage premium effect) on teachers' wage setting has driven higher per-pupil PEE.

The finding of this paper shows that the Baumol's effect in per-pupil PEE growth is much weaker than suggested by the Baumol's model. It is also small compared to the size of the Baumol's effect on health care spending found in the health care literature (Hartwig, 2008; Colombier, 2012). Instead, the result highlights that the change in wage premium contributes significantly to the per-pupil PEE growth. The result remains robust when the 
sample is restricted to the pre-global financial crisis period. The wage premium effect is found to be particularly strong in the middle-income countries and for countries with less developed education systems (with a large classroom size). Finally, we found that the wage premium effect is stronger for explaining the change in basic education expenditure, suggesting basic education is governed by the government's policy setting, whereas the Baumol's effect and capital education expenditure contributes more to the change in higher education expenditure.

This finding urges policymakers to pay closer attention to policies that have driven the strong wage premium effect, especially in the middle-income countries. Does the effect reflect the skill premium for teachers or overpayment for teachers owing to the country's institutional and political background? This paper provides two case studies in Indonesia and South Africa that seem to support the latter hypothesis and calls for reforms in rationalizing the wage-setting policy to improve the cost-effectiveness of public education service. However, this question needs further investigation using micro surveys available for other countries.

Finally, this paper also calls for further research to evaluate whether higher teachers' salaries and the wage premium have led to better educational outcomes. The previous study found that teachers are overcompensated in advanced economies, which is negatively associated with Organization for Economic Cooperation and Development's (OECD's) Programme for International Student Assessment (PISA) score (see Verhoeven, Gunnarsson, and Carcillo, 2007). This suggests that educational performance could have been improved with less education spending in advanced economies. This question has not been investigated in emerging and developing countries, and is left for future empirical investigations. 


\section{Appendix I. Data Description}

The data on education expenditure come from several sources. The main data source is the United Nations Educational, Scientific and Cultural Organization (UNESCO) Institute for Statistics which provides most comprehensive data on public education expenditure (including primary, secondary, and tertiary education). The missing values are filled by the Organization for Economic Cooperation and Development's (OECD's) Education database and by the World Bank's World Development Indicators (WDI). The data show not only educational expenditure as a share of GDP, but also actual educational expenditure levels per pupil for three levels of schooling: primary, secondary, and tertiary. The UNESCO database also provides details on educational expenditures by nature, dividing expenditure for educational personnel, other current expenditures, and capital expenditures.

The key variables in our econometric model are teachers' salaries and manufacturing wage. The wage data is from the International Labor Organization (ILO) labor statistics database, which provides the average monthly earnings of salaried employees (excluding manual workers) in education and manufacturing sectors. ${ }^{17}$ The earnings data cover gross remunerations in cash and in kind paid to employees for time worked, bonuses, allowances, and benefits (e.g., annual leave and other paid leave). Earnings exclude severance and termination payments. ${ }^{18}$ Data are disaggregated by economic activity according to the United Nation's International Standard Industrial Classification (ISIC) classification (ISIC Rev. 3.1 and Rev. 4). ${ }^{19}$

The average wage data is expressed in local currency and is recorded in different units (mainly monthly wages, but hourly, daily, weekly, or annual wages in a few cases), sometimes with breaks in the application of currency because of a change in national currency or the redenomination of old currency. ${ }^{20}$ For this reason, this paper undertook intensive data cleaning to ensure the consistency of nominal wage series, which is converted into annual wages in the current local currency unit. Owing to concerns about measurement errors, outliers (two standard deviations above and below the mean) are trimmed.

\footnotetext{
${ }^{17}$ The online database is publicly available at http://laborsta.ilo.org/.

${ }^{18}$ See the ILO's statistical glossary for details, available at http://laborsta.ilo.org/definition_E.html.

${ }^{19}$ The ILO data only provides the average wage for public education workers as a whole, and therefore it does not disaggregate the average wage by the level of education (primary, secondary, and tertiary level) and by the type of workers (teachers and administration staffs). One limitation of the ILO education wage data is that it covers workers in both public and private institutions. Therefore, the effect of the wage growth of teachers in private institutions needs to be controlled in the analysis.

${ }^{20}$ The average wages are mostly obtained from monthly payroll data available in censuses, establishment sample surveys, or household surveys in each country. Although hourly wages could better capture the wage difference depending on hours of service provision, the ILO database does not provide enough country-year observations on teachers' salaries and manufacturing wages to define the wage premium at hourly frequency.
} 
Wage data is available for many advanced and emerging economies, while it contains missing values for many low-income countries. When the ILO's wage data is not available, the average teacher salary is computed by dividing the wage bill data for public education with total employees in the public education sector. The wage bill in public education is also computed based on total public education spending and the share of recurrent spending for educational personnel (out of total education spending). The total employment in the education sector is drawn from the ILO's labor statistics.

Another important independent variable in our econometric analysis is the Baumol's variable as defined in Eq. (6). This variable is computed using the average economy-wide wage growth (from the ILO's database), the change in overall level of labor productivity, and the share of employment in public education. The overall level of labor productivity is computed by country and year using real GDP data (from the WDI) and total employment in the economy (from the ILO's labor statistics).

The remaining independent variables (real per capita GDP in purchasing power parity (PPP) international dollars, teacher-pupil ratio, school-age population, and school enrollment) come from the WDI database and United Nations (2013).

Consequently, the following 61 countries are included as the main sample in our econometric analysis.

Table A.1. Main Sample ${ }^{21}$

High-income countries (HICs; 32): Australia, Austria, Bahrain, Belgium, Canada, Cyprus, Czech Republic, Denmark, Finland, France, Germany, Greece, Iceland, Ireland, Israel, Italy, Japan, South Korea, Lithuania, Luxembourg, Malta, New Zealand, Norway, Poland, Portugal, Russia, Spain, Sweden, Switzerland, United Kingdom, United States, Uruguay.

Middle-income countries (MICs; 28): Argentina, Armenia, Azerbaijan, Brazil, Bulgaria, Chile, Costa Rica, Croatia, Dominican Republic, Ecuador, Egypt, El Salvador, Georgia, Indonesia, Kazakhstan, Kyrgyz Republic, Latvia, Malaysia, Mauritius, Mexico, Moldova, Nicaragua, Panama, Peru, Philippines, Romania, Thailand, Ukraine.

Low-income countries (LICs; 1): Bangladesh.

\footnotetext{
${ }^{21}$ The income group classification is based on the World Bank Atlas method where low-income economies are defined as those with a gross national income (GNI) per capita of \$1,045 or less in 2013; middle-income economies are those more than $\$ 1,045$ but less than $\$ 12,746$; high-income economies are those with $\$ 12,746$ or more.
} 


\section{Appendix II. Panel Unit Root and Cointegration Test}

The Fisher-type panel unit root tests (Maddala and Wu, 1999; Choi, 2001) are applied to see if the log differences of real per-pupil education spending, real per capita GDP, and real teachers' salaries are stationary. As the sample is unbalanced, the Fisher-type results (the augmented Dickey-Fuller, ADF, test statistics) are reported in the Table A.2.

In Table A.2, the test results refer to observations during the whole sample period (column 1) and during the pre-crisis period (1995-2006) (in column 2). Once these variables are firstdifferenced, the ADF test rejects the null hypothesis on the existence of unit roots for observations during the pre-crisis period.

Table A.2. Panel Unit Root Test Result

\begin{tabular}{|c|c|c|c|c|}
\hline & \multicolumn{2}{|c|}{$\begin{array}{c}(1) \\
\text { ADF - Fisher Chi-sq }\end{array}$} & \multicolumn{2}{|c|}{$\begin{array}{c}(2) \\
\text { ADF - Fisher Chi-sq }\end{array}$} \\
\hline & Stat & Prob & Stat & Prob \\
\hline \multicolumn{5}{|l|}{ H0: unit root (ADF-Fisher test) } \\
\hline Log (real per-pupil education spending) & 88.648 & 0.118 & 78.810 & 0.101 \\
\hline$\Delta$ Log (real per-pupil education spending) & 155.519 & 0.000 & 115.757 & 0.000 \\
\hline Log (per capita GDP in PPP\$) & 67.116 & 0.702 & 22.400 & 1.000 \\
\hline$\Delta$ Log (per capita GDP in PPP\$) & 63.265 & 0.703 & 109.781 & 0.000 \\
\hline Log (real teachers' salaries) & 74.228 & 0.471 & 76.052 & 0.144 \\
\hline$\Delta$ Log (real teachers' salaries) & 183.794 & 0.000 & 109.700 & 0.000 \\
\hline Sample & \multicolumn{2}{|c|}{ All } & \multicolumn{2}{|c|}{ Pre-crisis } \\
\hline
\end{tabular}

The presence of a unit-root justifies the estimation of cost factors determining the level of real per-pupil education expenditure in a vector error correction (VEC) model. ${ }^{22}$ The cost function includes the key determinants of per-pupil public education expenditure (PEE), such as per capita GDP (the so called "Wagner variable", in constant 2005 purchasing-powerparity-adjusted U.S. dollars) and real teachers' salaries (deflated by the GDP deflator). The Johansen Fisher panel cointegration test (Table A.3; trace test and maximum eigenvalue test) supports that the model is I(1), i.e., with one cointegrating vector, under different assumptions on intercept and time trend.

\footnotetext{
22 Similar analysis exists in public health literature (see Gerdtham and Lothgren, 2000, and Carrion-i-Silvestre, 2005), which test the "first law of health economics,", i.e., the relationship between total health spending per capita and GDP per capita. See Kuckuck (2014), Lamartina and Zaghini (2011) and Akitoby, Clements, and others (2006) for similar analysis on general government spending.
} 
Table A.3. Johansen Panel Cointegration Test

\begin{tabular}{lllll}
\hline Test type & No intercept & With intercept & \multicolumn{2}{l}{ With intercept } \\
& No trend & No trend & \multicolumn{2}{c}{ With linear trend } \\
\hline Trace test & & 1 & 1 & 1 \\
Maxeigenvalue test & & 1 & 1 & 1 \\
\hline
\end{tabular}

A cointegration test is performed with a one-year time lag. The critical value of 95 percent is used for hypothesis testing of the number of cointegrating relationships.

To distinguish comovements that are temporary in nature from comovements that reflect a steady state, the VEC model is run as defined below. It includes a one-year time lag and the time trend of per-pupil real education expenditure (on the basis of Wolff, Baumol, and Saini, 2014).

$$
\Delta \log E_{t}=\mu+\beta_{0} \Delta \log Y_{t}+\gamma\left[\log E_{t-1}-\delta \log Y_{t-1}\right]+\varepsilon_{t}
$$

where $E_{t}$ is per-pupil real PEE and $Y_{t}$ is real GDP per capita. $\beta_{0}$ is the short-term income elasticity of public education spending, while $\delta$ is the long-term income elasticity. The error correction term $\gamma\left[\log E_{t-t}-\delta \log Y_{t-1}\right]$ captures deviations from the steady state, and $\gamma$ is the rate at which education spending adjusts to past disequilibrium. We also add real teachers' salaries (which are the relative price between teachers' salaries and the GDP deflator) to estimate the price effect on public education spending.

In Table A.4, both the short-term and long-term income and price elasticities are estimated using the VEC model. Panel A shows the estimates in a cointegrating equation (representing the long-run relationship) while Panel B shows the income and price elasticities in the short term. For the whole sample (in column 1 of Panel A), the long-term income elasticity $(\delta)$ is significant and is 0.55 . When the sample is restricted to the pre-crisis period (in column 2 of Panel A), it is estimated at 1.15 , close to unity. This supports that consumers are priceinelastic for demanding education to accumulate human capital except in the global financial crisis period. On this basis, public education can be considered a luxury good, which is consistent with the Wagner's hypothesis in the context of public education.

In Panel B, the negative error correction term confirms the long-term relationship between public education spending and real GDP per capita. The short-term price elasticity is also found to be positive and significant, which supports that teachers' salaries are critical in explaining the short-term variation of per-pupil PEE. 
Table A.4. Vector Error Correction Model Estimate

\begin{tabular}{|c|c|c|}
\hline \multirow[t]{3}{*}{ VARIABLES } & \multicolumn{2}{|c|}{ Ln(real per-pupil public education expenditure) } \\
\hline & $(1)$ & (2) \\
\hline & All & Pre-crisis \\
\hline \multicolumn{3}{|c|}{ A. Cointegrating equation (long-term relationship) } \\
\hline \multirow[t]{2}{*}{ Ln(per capita GDP in PPP\$) (lag1) } & $0.546^{\star \star *}$ & $1.155^{\star * \star}$ \\
\hline & $(0.195)$ & $(0.097)$ \\
\hline \multirow[t]{2}{*}{ Ln(real teachers' salaries) (lag1) } & -0.030 & -0.015 \\
\hline & $(0.076)$ & $(0.039)$ \\
\hline \multicolumn{3}{|c|}{ B. Main equation (short-term relationship) } \\
\hline \multirow[t]{2}{*}{ Error correction term } & $-0.035^{\star \star *}$ & $-0.077^{\star \star *}$ \\
\hline & $(0.010)$ & $(0.025)$ \\
\hline \multirow[t]{2}{*}{$\Delta \mathrm{Ln}($ per capita GDP in PPP\$) } & 0.195 & 0.213 \\
\hline & $(0.128)$ & $(0.184)$ \\
\hline \multirow[t]{2}{*}{$\Delta \operatorname{Ln}($ real teachers' salaries $)$} & $0.116^{\star * *}$ & $0.112^{* * *}$ \\
\hline & $(0.041)$ & $(0.048)$ \\
\hline \multirow[t]{2}{*}{ Constant } & 0.009 & 0.006 \\
\hline & $(0.013)$ & $(0.015)$ \\
\hline Observations & 408 & 287 \\
\hline Adjusted R-squared & 0.136 & 0.145 \\
\hline Wald test F-stat & 13.822 & 10.705 \\
\hline
\end{tabular}

${ }^{* * *} p<0.01,{ }^{* *} p<0.05,{ }^{*} p<0.1$; robust standard errors in parentheses. The regression assumes one cointegrating vector and includes intercept and linear time trend. 


\section{Appendix III. Wage Premium in Public Education: Case Studies in Indonesia and South Africa}

In the main analysis, stronger wage premium effect is found to drive an increase in per-pupil public education expenditure (PEE) especially in middle-income countries (MICs). What does this strong wage premium effect represent? The policy implication would differ depending on the cause of the wage premium effect.

The wage gap between two sectors comes from two sources: (a) the difference in observable characteristics, such as skill level and gender, and (b) the difference in rent payment (Melly, 2005). This appendix summarizes previous studies on the wage gap and provides case studies on the source of the wage gap between education and other professions in two MICs (Indonesia and South Africa).

In the public sector as a whole, previous studies found a positive public-private wage gap that reflects higher average wages paid for public workers (see Castro, Salto, and Steiner, 2013, for case studies in the European Union; Melly, 2005, for Germany; and Nielsen and Rosholm, 2001, for Zambia). When the level of education attainment is controlled, the positive wage gap gets larger for low-skilled public workers (with only a basic education degree attained). Some studies looked at the evolution in public-private wage gap, finding an increase in the wage premium for public workers especially for older workers and workers with lower levels of education (Castro, Salto, and Steiner, 2013). A few studies examined the wage gap between public education workers and other professionals (see Asadullah, 2006, for case studies in Bangladesh; Hazans, 2010, for Latvia; Zymelman and DeStephano, 1989, for sub-Saharan Africa; and Mizala and Nopo, 2012, for Latin American countries). They generally found that the wage premium for public education workers varies widely across countries and over time. ${ }^{23}$

To deepen our understanding on the source of the wage premium in public education, this appendix applies the Oaxaca-Blinder decomposition method to decompose the wage gap between public education workers and manufacturing workers into workers' observable characteristics (differences in human capital and other personal characteristics) and unobservable rent payments. Next, we examine the evolution of the wage premium between public education and manufacturing after controlling for workers' skill level and their affiliation in a labor union.

For two countries (Indonesia and South Africa), we use their micro surveys (the National Socio-Economic Household Survey (Susenas) for Indonesia; and the Post-Apartheid Labor Market Surveys (PALMS) for South Africa). Table A.5 shows that public education workers

\footnotetext{
${ }^{23}$ In many cases, average teachers' salaries are found to be lower than average manufacturing wages. See Podgursky and Tongrut (2006) for the United States and Mizala and Nopo (2012) for Latin American countries.
} 
have been paid higher salaries than manufacturing workers at all quartiles for both countries. The wage gap tends to get narrower toward the upper percentile of the wage distribution compared to the lower percentile, which reflects large wage inequality within the manufacturing sector. Public education workers fared better at the lower tail of the wage distribution because their salary tends to be kept higher than the market wage regardless of their skills as the labor union in public education has stronger bargaining power to obtain higher wages.

In Table A.6, the Oaxaca-Blinder method decomposes total wage gap into explained component (estimated by observables such as age, sex, family size, education attainment, place of residence, and union affiliation) and unexplained (rent) component both at mean and median using the 2004 and 2007 surveys. At median (which is robust to outliers), both explained and unexplained components account for sizable portions of wage gaps in Indonesia and South Africa. In Indonesia, the explained component made a larger contribution to the wage gap in 2007 compared with 2004, which suggests a higher skill premium paid to high skill public education workers. On the other hand, in South Africa, the unexplained component made a larger contribution to the wage gap in 2007, which suggests the government's labor market policy and institutions drove an increase in wage premium in South Africa.

Finally, Figure A.1 shows the evolution of median wage gap between two sectors when workers' education level is controlled (i.e., no skill premium effect). ${ }^{24}$ As similarly found in other countries, the wage premium for public education workers has increased over time especially for low-skilled workers (with primary education level) both in Indonesia and South Africa. This demonstrates that low-skilled public education workers have been paid increasingly higher wages compared with manufacturing workers owing to an increase in wage premium to public workers as governed by the government's wage-setting policy.

This finding corresponds well with the institutional background where the public sector provides more favorable compensations, higher job security and stronger unionization, and political clout for older workers with senior positions despite sometimes with lower education level. However, similar analysis is needed using micro surveys in other countries to design appropriate policy in public education expenditure because the source of the wage premium would be different depending on each country's labor market institutions.

\footnotetext{
${ }^{24}$ For South Africa, PALMS contains information on households' affiliation in a labor union. Given that a labor union plays a large role in the wage negotiation in South Africa, this analysis restricted its sample to workers who are affiliated with a labor union to rule out the effect of unionization on the wage gap.
} 
Table A.5. Wage Gap at Different Quantiles in Indonesia and South Africa

\begin{tabular}{l|r|r|rrrr}
\hline & \multicolumn{1}{|c|}{$\mathrm{N}$} & \multicolumn{1}{c|}{ Mean } & \multicolumn{1}{c}{ p25 } & p50 & p75 & p90 \\
\hline Indonesia & & & & & & \\
\hline Log wage in education (in 2004) & 942 & 13.923 & 13.682 & 14.078 & 14.241 & 14.457 \\
Log wage in manufacturing (in 2004) & 3919 & 13.533 & 13.218 & 13.528 & 13.816 & 14.221 \\
\hline$\quad$ Wage gap in 2004 & & 0.390 & 0.464 & 0.550 & 0.425 & 0.236 \\
\hline Log wage in education (in 2007) & 907 & 14.210 & 13.911 & 14.403 & 14.604 & 14.897 \\
Log wage in manufacturing (in 2007) & 3184 & 13.709 & 13.305 & 13.700 & 14.078 & 14.509 \\
\hline$\quad$ Wage gap in 2007 & & 0.501 & 0.606 & 0.703 & 0.526 & 0.388 \\
\hline South Africa & & & & & & \\
Log wage in education (in 2004) & 1514 & 8.318 & 8.006 & 8.517 & 8.854 & 9.018 \\
Log wage in manufacturing (in 2004) & 4115 & 7.338 & 6.764 & 7.352 & 7.903 & 8.517 \\
\hline$\quad$ Wage gap in 2004 & & 0.980 & 1.242 & 1.166 & 0.950 & 0.501 \\
\hline Log wage in education (in 2007) & 1899 & 8.382 & 8.006 & 8.700 & 8.995 & 9.240 \\
Log wage in manufacturing (in 2007) & 4602 & 7.536 & 6.987 & 7.575 & 8.086 & 8.700 \\
\hline$\quad$ Wage gap in 2007 & & 0.847 & 1.019 & 1.125 & 0.910 & 0.541 \\
\hline
\end{tabular}

Sources: Susenas, PALMS, and IMF staff calculations.

Note: Susenas sample coverage is restricted to households in urban zones in Jakarta and Java. The sample covers all workers regardless of their union affiliation.

Table A.6. Decomposition Estimates in Indonesia and South Africa

\begin{tabular}{|c|c|c|c|c|}
\hline \multirow[t]{2}{*}{ Indonesia } & \multicolumn{2}{|c|}{2004} & \multicolumn{2}{|c|}{2007} \\
\hline & Mean & Median & Mean & Median \\
\hline Raw wage gap & 0.367 & 0.550 & 0.430 & 0.693 \\
\hline (=Education - Manufacturing) & $(0.052)$ & (0.018) & $(0.054)$ & (0.009) \\
\hline \multirow[t]{2}{*}{ Explained component } & 0.189 & 0.286 & 0.254 & 0.491 \\
\hline & $(0.045)$ & $(0.028)$ & $(0.037)$ & $(0.066)$ \\
\hline \multirow[t]{2}{*}{ Unexplained component } & 0.178 & 0.264 & 0.177 & 0.203 \\
\hline & $(0.058)$ & $(0.004)$ & $(0.055)$ & $(0.017)$ \\
\hline \multirow[t]{2}{*}{ South Africa } & \multicolumn{2}{|c|}{2004} & \multicolumn{2}{|c|}{2007} \\
\hline & Mean & Median & Mean & Median \\
\hline Raw wage gap & 0.864 & 1.104 & 0.724 & 1.027 \\
\hline (=Education - Manufacturing) & $(0.025)$ & $(0.020)$ & $(0.025)$ & $(0.015)$ \\
\hline \multirow[t]{2}{*}{ Explained component } & 0.783 & 0.900 & 0.744 & 0.764 \\
\hline & $(0.034)$ & $(0.064)$ & $(0.027)$ & $(0.055)$ \\
\hline \multirow[t]{2}{*}{ Unexplained component } & 0.082 & 0.204 & -0.019 & 0.263 \\
\hline & $(0.039)$ & $(0.014)$ & $(0.031)$ & $(0.015)$ \\
\hline
\end{tabular}

Sources: Susenas, PALMS, and IMF staff calculations.

Note: Susenas sample coverage is restricted to households in urban zones in Jakarta and Java. Mean effect is estimated by the Oaxaca-Blinder decomposition. Median effect is estimated by the quantile regression technique (developed by Melly, 2005) and the standard errors are estimated by bootstrapping the results 50 times. 
Figure A.1. Median Wage Gap between Public Education and Manufacturing Sector: by Level of Education Attainment

(Percent of Manufacturing Sector Wage)

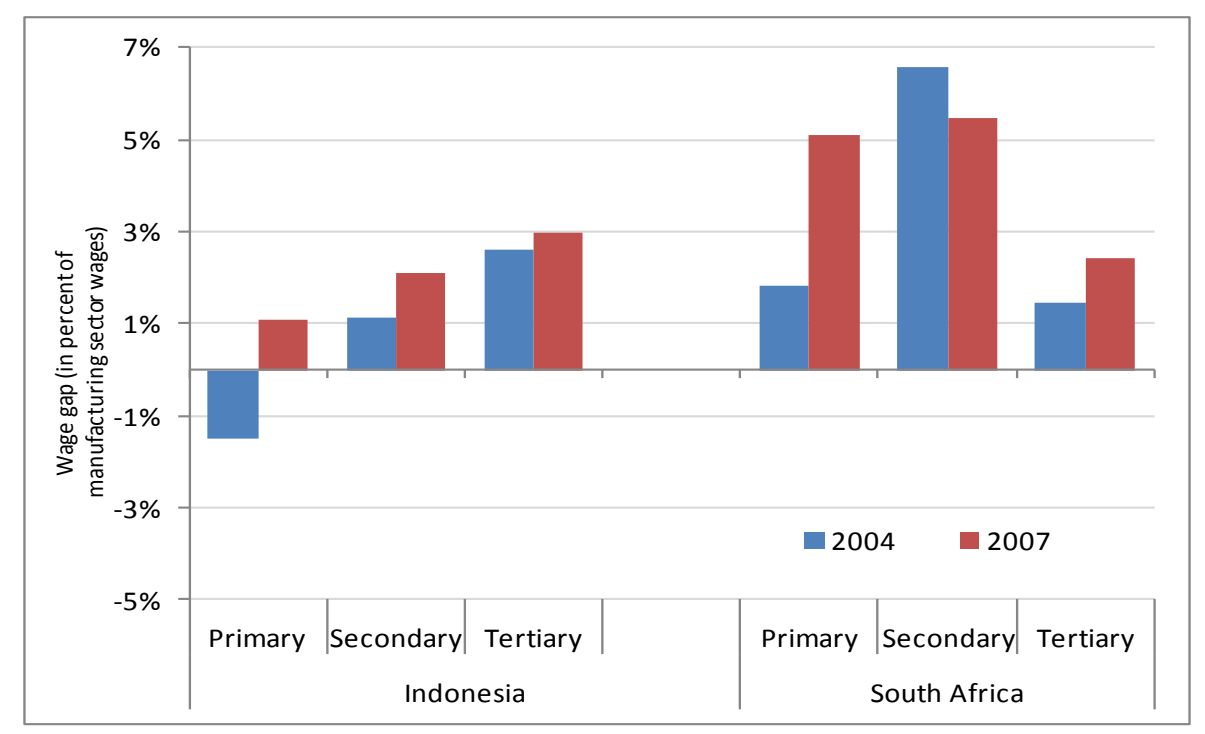

Sources: Susenas, PALMS, and IMF staff calculations.

Note: For South Africa, the sample covers only workers who are the member of the labor union to control for the unionization effect on the wage gap between public education and manufacturing. 


\section{References}

Akitoby, B., B. Clements, S. Gupta, and G. Inchauste, 2006, "Public Spending, Voracity, and Wagner's Law in Developing Countries," European Journal of Political Economy, Vol. 22, pp. 908-24.

Asadullah, M., 2006, "Pay Differences between Teachers and Other Occupations: Some Empirical Evidence from Bangladesh,” Journal of Asian Economics, Vol. 17, pp. 1044-65.

Bates, L., and R. Santerre, 2013, "Does the U.S. Health Care Sector Suffer from Baumol's Cost Disease? Evidence from the 50 States," Journal of Health Economics, Vol. 32, pp. 386-91.

Baumol, W., 1967, "Macroeconomics of Unbalanced Growth: The Anatomy of Urban Crisis," American Economic Review, Vol. 57, No. 3, pp. 415-26.

Baumol, W., D. Ferranti, M. Malach, A. Pablos-Mndez, H. Tabish, and L.Wu, 2012, The Cost Disease: Why Computers Get Cheaper and Health Care Doesn't (New Haven: Yale University Press).

Carrion-i-Silvestre, J., 2005, "Health Care Expenditure and GDP: Are They Broken Stationary?" Journal of Health Economics, Vol. 24, pp. 839-54.

Castro, F., M. Salto, and H. Steiner, 2013, "The Gap between Public and Private Wages: New Evidence for the EU," European Commission Economic Paper 508 (Brussels: European Economic Commission).

Choi, I., 2001, "Unit Root Tests for Panel Data," Journal of International Money and Finance, Vol. 20, pp. 249-72.

Clements, B., S., Gupta, I., Karpowicz, and S. Tareq, 2010, "Evaluating Government Employment and Compensation," IMF Fiscal Affairs Department, Technical Notes and Manuals (Washington: International Monetary Fund).

Colombier, C., 2012, “Drivers of Health Care Expenditure: Does Baumol's Cost Disease Loom Large?” FiFo Discussion Paper No. 12-5.

European Commission, The 2012 Ageing Report: Economic and BudgetaryProjections for the EU-27 Member States (2010-2060), European Economy 2/2012 (Brussels:

Directorate General for Economic and Financial Affairs of the European Union).

Gerdtham, U., and M. Lothgren, 2000, "On Stationarity and Cointegration of International Health Expenditure and GDP," Journal of Health Economics, Vol. 19. pp. 461-75.

Glewwe, P., and M. Kremer, 2006, "Schools, Teachers, and Education Outcomes in Developing Countries," Chapter 16 in Handbook of the Economics of Education, Vol. 2, pp. 945-1017. 
Grigoli, F., 2014, "A Hybrid Approach to estimating the Efficiency of Public Spending on Education in Emerging and Developing Economies," IMF Working Paper WP/14/19 (Washington: International Monetary Fund).

Gupta, S., and M. Verhoeven, 2001, “The Efficiency of Government Expenditure: Experiences from Africa," Journal of Policy Modeling, Vol. 23, pp. 433-67.

Hartwig, J., 2008, "What Drives Health Care Expenditure? Baumol's Model of 'Unbalanced Growth' Revisited," Journal of Health Economics, Vol. 27, pp. 603-23.

Hazans, M., 2010, “Teacher Pay, Class Size and Local Governments: Evidence from the Latvian Reform," IZA Discussion Paper No. 5291.

Herrera, S., and G. Pang, 2005, "Efficiency of Public Spending in Developing Countries: An Efficiency Frontier Approach," World Bank Policy Research Working Paper No. 3645 (Washington: World Bank).

IMF, 2010, "Macro-Fiscal Implications of Health Care Reform in Advanced and Emerging Economies," (Washington: International Monetary Fund).

_ 2013, "Portugal: Rethinking the State-Selected Expenditure Reform Options," IMF Country Report No. 13/6 (Washington: International Monetary Fund).

_ 2014, "Public Expenditure Reform: Making Difficult Choices," Fiscal Monitor, April.

Kuckuck, J., 2014, “Testing Wagner's Law at Different Stages of Economic Development," FinanzArchiv, Vol. 70, No. 1, pp. 128-68.

Lamartina, S., and A. Zaghini, 2011, "Increasing Public Expenditure: Wagner's Law in OECD Countries," German Economic Review, Vol. 12, pp. 149-64.

Maddala, G.S., and S. Wu, 1999, "A Comparative Study of Unit Root Tests with Panel Data and New Simple Test," Oxford Bulletin of Economics and Statistics, Vol.61, pp.631-52.

Medeiros, J., and C. Schwierz, 2013, "Estimating the Drivers and Projecting Long-term Public Health Expenditure in the European Union: Baumol's Cost Disease Revisited," European Commission, Economic Papers 507 (Brussels: European Economic Commission).

Melly, B., 2005, "Public-private Sector Wage Differentials in Germany: Evidence from Quantile Regression," Empirical Economics, Vol. 30, pp. 505-20.

Mishel, L., and R. Rothstein, 2002, “The Class Size Debate,” Economic Policy Institute, Washington, DC.

Mitch, D., 2004, "School Finance," in International Handbook on the Economics of Education, G. Johnes and J. Johnes, eds., Cheltenham, UK: Edward Elgar Publishing, pp. 260-98. 
Mizala, A., and H. Nopo, 2012, "Evolution of Teachers' Salaries in Latin America at the Turn of the $20^{\text {th }}$ Century: How Much Are They (Under or Over) Paid?" IZA Discussion Paper No. 6806.

Nielsen, H., and M. Rosholm, 2001, "The Public-Private Sector Wage Gap in Zambia in the 1990s: A Quantile Regression Approach,” Empirical Economics, Vol. 26, pp.169-82.

Nordhaus, W., 2008, “Baumol's Diseases: A Macroeconomic Perspective,” The B.E. Journal of Macroeconomics, Vol. 8, Issue 1, pp. 1-37.

Organisation for Economic Co-operation and Development, Education at a Glance 2012: OECD Indicators (Paris).

—., Education at a Glance 2013: OECD Indicators (Paris).

Podgursky, M., and R. Tongrut, 2006, “(Mis-)Measuring the Relative Pay of Public School Teachers: Education Finance and Policy," Education Finance and Policy, Vol. 1, No. 4, pp. $425-40$.

Psacharopoulos, G., and H. Patrinos, 2004, "Returns to Investment in Education: A Further Update," Education Economics, Vol. 12, No. 2, pp. 111-34.

UNESCO Institute for Statistics, 2010, Methodological Guide for the Analysis of Teacher Issues (Paris: UNESCO).

— 2011, Financing Education in Sub-Saharan Africa: Meeting the Challenges of Expansion, Equity, and Quality (Paris: UNESCO).

United Nations, 2013, World Population Prospects: The 2012 Revision, Volume I: Comprehensive Tables, ST/ESA/SER.A/336 (New York: United Nations, Department of Economic and Social Affairs, Population Division).

Verhoeven, M., V. Gunnarsson, and S. Carcillo, 2007, "Education and Health in G7 Countries: Achieving Better Outcomes with Less Spending," IMF Working Paper WP/07/263 (Washington: International Monetary Fund).

Wolff, E., W. Baumol, and A. Saini, 2014, "A Comparative Analysis of Education Costs and Outcomes: The United States vs. Other OECD Countries," Economics of Education Review, Vol. 39, pp. 1-21.

Zymelman, M., and J. DeStephano, 1989, "Primary School Teachers' Salaries in SubSaharan Africa," World Bank Discussion Paper 45 (Washington: World Bank). 